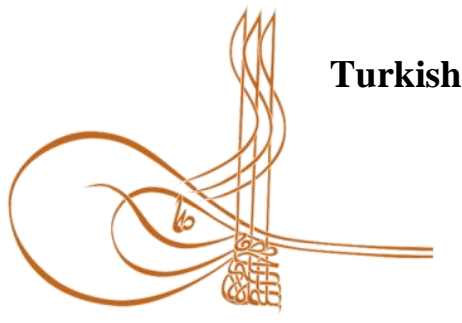

www.turkishstudies.net/appliedsciences
eISSN: 2667-5633

Research Article / Araştırma Makalesi

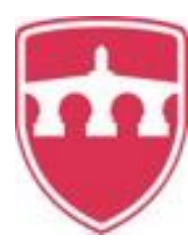

INTERNATIONAL

BALKAN

UNIVERSITY

Sponsored by IBU

\title{
Analog Fotoğraftan Dijital Fotoğrafa Geçişte Fotoğrafik Gerçekliğin Dönüşümü
}

\author{
The Transformation of Photographic Reality in Transition from Analog to Dijital Photography
}

\author{
Ülhak Çimen*
}

\begin{abstract}
After the invention of the camera, it became questionable whether the photographic technology represented reality or to what extent it represented reality. The first period of reality debates focused on mainly about the replacement of reality with elements such lens selection, depth of field, exposure, angle, framing and composition, while recent reality debates are about the disappearance of human qualities (illusion, idea, consciousness, image, desire, scene, relationship). Again, the current debates that in the digital image era, photography has disappeared, that the image cannot understand digital images, that the subjective aspect of reality has been destroyed, and that there has been a different visual image era that cannot be called a photo. While the concepts of natural magic, illusion, thinking, appearing and disappearing gained during the analogue period of the photograph refer to the reality of the photograph and give the photograph a unique form, the ready-made codes loaded on the camera before the photographing process; manipulations and algorithmic processes during shooting have eliminated the reality of the photograph. In this study, the notion of reality was put into a conceptual framework and definition and the transformation of photographic reality with the transition from analogue photography to digital photography was tried to be explained and literature review method was used. In this study, the concepts such as aura (halo), spectra, studium, punctum, which are used to explain photographic reality are discussed in the context of analog and digital photography and the human aspect of reality is aimed to be revealed.
\end{abstract}

Structured Abstract: After the invention of the camera, it became questionable whether the photographic technology represented reality or to what extent it represented reality. The first period of reality debates focused on mainly about the replacement of reality with elements such lens selection, depth of field, exposure, angle, framing and composition, while recent reality debates are about the disappearance of human qualities (illusion, idea, consciousness, image, desire, scene, relationship). Again, the current debates that in the digital image era, photography has disappeared, that the image cannot understand digital images, that the subjective aspect of reality has been destroyed, and that there has been a different visual image era that cannot be called a photo.

The insatiable background of the photographing eye has a lot to consider. First of all, the originality and ethics of the photographic image were present in the era of analogue photography. While having a photographic image is a means of reaching the world and world reality, it has started to deviate from a path

\footnotetext{
* Dr. Öğr. Üyesi, Atatürk Üniversitesi, İletişim Fakültesi, Radyo, Sinema ve Televizyon Bölümü Asst. Prof. Dr. Ataturk University, Faculty of Communication, Department of Radio, Cinema and Television ORCID 0000-0002-7307-4874

ulhakcimen@gmail.com

Cite as/ Atıf: Çimen, Ü. (2020). Analog fotoğraftan dijital fotoğrafa geçişte fotoğrafik gerçekliğin dönüşümü, Turkish Studies-Applied Sciences, 15(1), 15-37. https://dx.doi.org/10.29228/TurkishStudies.40533

Received/Geliş: 13 January/Ocak 2020

Accepted/Kabul: 25 March/Mart 2020

Checked by plagiarism software

Copyright $(C)$ INTAC LTD, Turkey

Published/Yayın: 30 March/Mart 2020

CC BY-NC 4.0
} 
which is not clear what it serves in digital photography. Photographing something in analogue photography has been a way of capturing it, the power of imagination, the multidimensionality of thinking, the beauty of criticism, the mysteriousness of knowing, and the commodity phase of communicating with the object, but a differentiated form of looking at speed without being sacrificed.

While analog photographs obtained with human qualities such as emotion, thought, aesthetic anxiety, image, illusion, consciousness, thought etc. are considered as pure reality, digital photographs obtained with pre-prepared codes are ignored and new reality, obvious reality, post reality, super reality, photography post reality is considered as holistic reality. Digital photography is a new conception of reality, pointing to a different, constructed and coded and pre-constructed reality in which the human aspect of reality is ignored.

The study is considered important in terms of showing that human qualities are gradually disappearing with the advances in photographic technology and that people are dependent on technological innovations. With the transition from analog photo to digital photo, the meaning to be uploaded to the photo is formed by the guidance of various digital technologies predetermined outside of us. However, the photographer doesn't know much about the orientation, and with Barthes' discourse, he feels as if he is creating the message without the code. Digital photographs that want built-in meanings to be obeyed try to make people feel that they are creative in the whole process of meaning by presenting indexical naturalness in what we see. In reality, the hegemony of photographic technology that disables the human being is taking place.

The concept of traditional reality is closely related to thought. In analog photography, the photographer takes action by taking into consideration the thoughts and practices connected with thinking and creates meaning in the photography. Debates on the reality of photography remain insignificant unless the relationship between photography and thought is established. Reality has both objective and subjective aspects. To characterize reality as a world on its own out of personal perception leads to deficiencies in the definition of reality. This study defines reality as coinciding with the sum of the relationship between the subjective and the objective. With the advances in technological developments - that is, the transition to digital photography - the nature of photographic reality has been disrupted and added value has been added to objectivity. This added value does not mean a positive meaning but a negation. If it can be said, the meaning of vision has been added to the concept of seeing by expanding the field of exploration seen by the eye. Digital photographs produced with digital technologies constitute virtual representations. Therefore, it is not possible to see causality and spatial and temporal dependencies that we face in analog photography in digital photographs. Digital outputs produced from raw and coded data by algorithmic logic are a new image technology in which human factor is minimized and thought is ignored. In these technologies, the fractal dimension of reality, which is digitized and manipulated by destroying the human aspect of reality, which is evident in perception to objects, is emerging.

The image taken in digital photography can be seen on the screen at the same time, so images, thinking, criticism, talisman, ethics, aesthetics etc. are not realized. While the analog photograph, where a definite time frame is introduced instead of the stream and the photograph is expected, digital photographs reflecting a stream come and create temporary superficial pathos. Digital photography is a system in which binary system consisting of 0 and 1 , which complies with computer logic, combines image and reality on the same screen and disables thought.

It is necessary to look for the photo in the mind of the photographer rather than the operation of the camera. Because what brings out photography is intelligence, imagination, creativity, consciousness and ability to describe. In this sense, photographic creativity should be more meaningful and important than camera and photographic technologies. While the camera cannot be of any purpose, human thinking has the goal of purposeful transformation. In photographing, reality must be related not only to light reflected from objects, but also to illusion. Previously, the reality seen by the naked eye and the reality seen by the lens were not always the same. However, he managed to create his own photographic reality with digital photography and transform the super reality, digital reality, which is in accordance with predetermined software and codes.

While the subjective and objective aspects of reality can create awareness on photography in subjective photography, subjective awareness in digital photography has been made unimportant and objective reality has transcended the reality of the object and made a different state of reality an image. The study aims to show the transformation of reality with the transition from analog photo to digital photo. Again, the study

Turkish Studies - Applied Sciences, 15(1) 
aims to show that the importance given to human beings gradually diminishes during the current photography and that technological orientations make the awareness unnecessary.

Keywords: reality, photographic reality, analogue photograph, digital photograph, illusion, idea.

Öz: Fotoğraf makinesinin icadından hemen sonra fotoğraf teknolojisinin gerçekliği temsil edip etmediği veya ne derece temsil ettiği tartışlır hale gelmiştir. İlk dönem gerçeklik tartı̧maları daha çok objektif seçimi, alan derinliği, pozlama, açı, çerçeveleme ve kompozisyon gibi öğelerle gerçekliğin değiştirildiği üzerineyken son dönem gerçeklik tartışmaları ise insani niteliklerin (yanılsama, düşünme, bilinç, ayartma, imge, arzu, sahne, ilişki, simgesellik gibi) yok olduğu üzerinedir. Yine güncel tartışmalar dijital imaj döneminde artık fotoğrafın ortadan kaybolduğu, imgenin dijital imajları anlayamayacağı, gerçekliğin öznel yönünün yok edildiği ve ismine fotoğraf denilemeyecek farklı bir görsel imaj dönemine geçildiği hususundadır. Fotoğrafin analog döneminde kazanmış olduğu doğal sihir, yanılsama, düşünme, belirme ve kaybolma kavramları fotoğrafın gerçekliğine gönderme yaparken ve fotoğrafı nevi şahsına münhasır bir form halini kazandırırken; dijital fotoğraflarda fotoğraflama sürecinden önce fotoğraf makinesine yüklenen hazır kodlar, çekim esnasında meydana gelen manipülasyonlar ve algoritmik işlemler fotoğrafın gerçekliğini ortadan kaldırmıştır. $\mathrm{Bu}$ çalışmada, gerçeklik nosyonu kavramsal bir çerçeveye ve tanımlamaya oturtularak analog fotoğraftan dijital fotoğrafçılığa geçişle birlikte fotoğrafik gerçekliğin dönüşümü açıklanmaya çalışılmış ve litaratür taraması yöntemine başvurulmuştur. Yine çalışmada fotoğrafik gerçekliği izah etmede kullanılan aura (hale), tayf, studium, punctum gibi kavramlar analog ve dijital fotoğraf̧̧ılık bağlamında ele alınarak gerçekliğin insani yönünün ortaya konulması amaçlanmıştır.

Anahtar Kelimeler: gerçeklik, fotoğrafik gerçeklik, analog fotoğraf, dijital fotoğraf, yanılsama, düşünce.

\section{Giriş}

Fotoğraf tarihinde üç ayrı süreç olduğu düşünülmektedir:

Birinci süreç gerçekliğin kopyalanmas1,

İkinci süreç fotoğrafın kitlesel üretimi,

Üçüncü süreç ise bilgisayar teknolojisi ile fotoğrafın dönüşümüdür ki bu durum gerçekliğin düşünce ile bağının koptuğu post fotoğrafik dönem yani yaşadığımız zamandır (Ökten, 2013:170171). Birinci süreç gerçekliğin kopyalanmaya çalışıldığ 1 fotoğrafin ilk icat dönemine; ikinci süreç analog fotoğraf teknolojisine ve bu teknolojinin kitlesel olarak yaygınlaşmasına; üçüncü süreç fotoğraf makinesinin insanı niteliklerden tamamen bağımsız hale geldiği dijital döneme denk gelmektedir.

Ökten ise fotoğraf tarihini iki döneme ayırmıştır:

"Birinci dönem, klasik karanlık oda tekniklerinin ve kimyasalın kullanıldı̆̆ dönem yani geleneksel fotoğraf dönemi, ikinci dönem ise teknolojinin ve sayısal veri tabanlarının kullanıld $\breve{g} l$ dönem yani dijital fotoğraf dönemi" (Ökten, 2013:25-26).

Geleneksel fotoğraf dönemi analog fotoğrafçıllı̆a, dijital fotoğraf dönemi ise güncel sayısal fotoğrafçılık dönemine denk düşmektedir.

Baudrillard gerçekliğin dönüşümünde dört farklı döneme işaret etmiştir. Bunlar;

-Rönesans’tan Sanayi Devrimi'ne klasik dönemi belirleyen biçim; mimesis (taklit) ve kopyalama dönemi,

-Sanayileşme dönemine egemen olan üretim dönemi,

-Kodun belirleyici olduğu simülasyon dönemi, 
-Gerçeklikle bütün bağlantısını koparan ve fraktalın bile bütüne gönderme yaptığı bütünsel gerçeklik dönemi (Baudrillard, 2016:12).

Birinci dönem gerçeklik; dışarıdaki bir nesnenin taklidine ve kopyalanmasına gönderme yapmaktadır ki bu dönem fotoğrafın icadının öncesine yani resim sanatına gönderme yapar. İkinci dönem gerçeklik; fotoğraf makinelerinin icadına gönderme yapmaktadır ki bu dönem sanayileşme döneminin başlangıcına denk düşer. Üçüncü dönem gerçeklik fotoğrafin kitlesel olarak üretilmesine ve yaygınlaşmasına gönderme yapmaktadır ki bu dönem analog fotoğrafın seri üretimini işaret eder. Dördüncü dönem gerçeklik, fotoğraf çekiminin fotoğraf makinelerinden bağımsız hale gelerek yaşamın her anını işgal etmesine gönderme yapmaktadır ki bu dönem dijital fotoğrafçılığın egemen olduğu günümüz dünyasıdır.

Bir fotoğrafın gerçeği ne kadar gösterebildiği ilk dönem örneklerinden başlayarak günümüze kadar devam etmiştir. Fotoğrafın gerçeklikle ilişkisindeki tartışmaların sürekliliğinde en büyük neden gerçekliğe yüklenen anlamın ve tanımlama sınırlarının belli edilmemesidir. Analog fotoğraf döneminde fotoğrafik görüntünün gerçeklikle yakın ilişkisinin olduğu ve dijital fotoğrafa geçişle birlikte fotoğrafın gerçeklikle ilişkisinin yok olduğu veya farklı bir gerçeklik durumuna geçildiği iddia edilmektedir (Baudrillard, 2012:1). Gerçeklik nosyonunun genel-geçer bir tanımının olmaması ve farklı disiplinlerin gerçekliğe farklı anlamlar yüklemesi gerçeklik hakkında söylenmek istenilen şeylerle anlaşılan şeylerin tam olarak örtüşmemesine yol açmaktadır. Gerçekliğin ne olduğunun belirgin olmaması fotoğrafin sunduğu gerçekliği de sürekli tartışılır hale getirmiştir (Walden, 2018:117). Fotoğrafin gerçeklikle olan ilişkisine değinmek geneli itibariyle fotoğraf görüntüsünün büyük oranda nesnel olduğunu iddia etmeye ya da gerçekliğin insani özelliklerle ilişkisine gönderme yapmaktadır (Freeland, 2018:71). Bu çalışmada gerçekliğin yanılsama ile ilişkisi göz önünde bulundurularak (Walton, 2018:44-45) fotoğrafik gerçeklik ele alınmaya çalışılmıştır. Bu anlamda görüntülerin gerçek olduğu düşüncesinin yanılsama olduğu düşünülmektedir (Freund, 2016:143). Gerçeklik kavramını nesnel kavramıyla eş değer tutarak zihinsel tasavvuru devre dışı bırakan anlayış gerçeklik kavramının anlamını bozmaktadır (Walden, 2018:130). Resmin egemenliğini aşan doğayı ve yaşamı, fizik ve kimya yoluyla aktarma çabaları sonucunda gelişen fotoğrafçılık anlayışının nesnelliğe indirgenerek öznelliğe bağlı referansların devre dışı bırakılması fotoğrafın değerlendirilmesini zorlaştırmaktadır (Özel, 2005: 274-275).

\section{1-Çalışmanın Önemi ve Amacı}

Çalışma fotoğraf teknolojisindeki gelişmelerle birlikte insani niteliklerin giderek ortadan kalktığını ve insanların teknolojik yeniliklere bağımlı kaldıklarını göstermesi bağlamında önemli görülmektedir. Analog fotoğraftan dijital fotoğrafa geçişle birlikte fotoğrafa yüklenecek anlam bizim haricimizde önceden belirlenmiş çeşitli sayısal teknolojilerin yönlendirmeleriyle oluşmaktadır. Lakin fotoğraf çeken kişi yönlendirmelerin çok fazla bilincinde olmamakta Barthes'in söylemiyle sanki kodu olmayan mesajı kendisi oluşturuyormuş gibi hissetmektedir (Barthes, 1982:17). İnşa edilmiş anlamlara uyulmasını isteyen dijital fotoğraflar gördüğümüz şeylerde dizinsel doğallık sunarak bütün anlam yaratım sürecinde fotoğrafı çeken kişinin yaratıcı olduğunu hissettirmeye çalışmaktadır. Gerçekte ise insanı devre dışı bırakan fotoğraf teknolojisinin hegemonyası gerçekleşmektedir.

Analog fotoğrafçılıkta gerçekliğin öznel ve nesnel yanı fotoğraf üzerinde bir bilinç oluşturabiliyorken dijital fotoğrafta öznel bilinç önemsiz hale getirilmiş ve nesnel gerçeklik nesneye ait gerçekliği aşarak farklı bir gerçeklik durumunu imaj haline getirmiştir. Çalışma analog fotoğraftan dijital fotoğrafa geçişle birlikte gerçekliğin dönüşümünü göstermeyi amaçlamaktadır. Yine çalışma mevcut fotoğrafçılık döneminde insana verilen önemin giderek azaldığını ve teknolojik yönlendirmelerin bilinci gereksiz kıldığını göstermeyi hedeflemektedir. 


\section{1-1 Çalışmanın Yöntemi}

Gerçeklik hakkında yapılan çalışmaların eksik kalmasındaki en önemli sebebin gerçeklik nosyonunun tanımlamasının tam olarak yapılmaması gösterilmektedir. Çalışmamızda literatür taraması yapılarak özellikle gerçeklik ve fotoğrafik gerçeklik belirli bir çerçeveye oturtulmuş; teknik terminolojiler kavramsal düzlemde tanımlanmıştır. Ayrıca literatür taraması yapılırken konunun kavramsal çerçevesini belirlemek amacıyla iletişim bilimlerinin yanı sıra; felsefe, sosyoloji, psikoloji ve eğitim bilimleri gibi alanlardan da yararlanılmıştır.

\section{1-2 Kavramsal Çerçeve}

Çalışmamızda kavramsal çerçeveyi belirleyen gerçeklik, fotoğrafik gerçeklik, analog fotoğraf ve dijital fotoğraf nosyonları açıklanmıştır.

1-2-1 Gerçeklik: Gerçekliğin hem nesnel hem de öznel yanı bulunmaktadır. Gerçekliği kişisel algının dışında kendi başına var olan bir dünya olarak nitelemek gerçekliğin tanımlamasında eksikliklere yol açmaktadır. Gerçekliğin bütünü, öznel ve nesnel olanın ilişkisinin toplamına denk düşmektedir (Fischer, 1990:179-205). Gelişen teknolojik gelişmelerle birlikte fotoğrafik gerçekliğin doğası bozularak nesnelliğe katma değer kazandırılmıştır. Bu katma değer olumlu bir anlamı değil olumsuzluğu ifade etmektedir. Denilebilirse gözün gördüğü keşfetme alanını genişleyerek görme kavramına yeni anlam yüklemesi yapılmıştır.

1-2-2 Fotoğrafik Gerçeklik: Fotoğrafik gerçeklik kavramı elde edilen bir fotoğraf görüntüsünün insani niteliklerle bağlantısını ifade etmek için kullanılmaktadır. Bu türden bir gerçeklik imge, yanılsama, bilinç, bekleme, ayartma, bilinç, görme, hayal kurma, çatışma, arzu gibi öznel değerlerle iç içe bulunmaktadır.

1-2-3 Analog Fotoğraf: Analog fotoğraf, cisimlerden yansıyan fotonların objektif tarafindan toplandığı ve sonrasında ışık enerjisinin elektrik enerjisine çevrilmesi sonucunda kimyasal işlemlerle kayıt altında tutulduğu sistemin adıdır (Arnheim, 1957:8). Analog fotoğraf makinelerinde elde edilen bir görüntünün eş zamanlı olarak ekranda gözükmesi mümkün değildir. Analog fotoğrafçılıkta elde edilebilecek fotoğraf sayısı sınırlıdır.

1-2-4 Dijital Fotoğraf: Dijital fotoğraf; fotonların, üzerinde milyonlarca piksel barındıran sensörler üzerine düşerek yarı iletken bir bölgede elektronlara dönüşmesi neticesinde önceden belirlenmiş kodlara göre sinyallerin güçlendirildikten sonra algoritmik olarak tasarlanan sayısal kayıt bölgelerine kaydedildiği görüntülere denilmektedir. Dijital fotoğraf makinelerinde elde edilen bir görüntünün eş zamanlı olarak ekranda gözükmesi mümkündür. Dijital fotoğrafçılıkta elde edilebilecek fotoğraf sayısı neredeyse sınırsızdır.

\section{2-Fotoğrafik Gerçekliğin Dönüşümü}

\section{2-1 Kitlesel Yeniden Üretimin Aracı Olarak Fotoğraf:}

Erken dönem fotoğraf çekimlerinde elde edilen görüntülerin kalıcı olması amaçlanmıștır (Benjamin, 2018:15). Bu amaçla elde edilen fotoğraflar tab ve banyo işlemlerinden sonra albümlerde ve çerçevelerde saklanmaktaydı. Ayrıca bu fotoğraf çıktılarına kıymetli eser muamelesi yapılmaktaydı. Modern yaşamda önemi giderek artan fotoğrafçılık önceleri sadece fotoğraf makineleri marifetiyle sonuçlar verirken şimdilerde cep telefonları, ipadler, tabletler, akıllı cep telefonları vs aracıllı̆ıyla da gerçekleştirilmektedir. Mevcut dünyamızda fotoğrafla ilintili olmayan etkinlik sayısı neredeyse kalmamıştır (Freund, 2016:8). Önceleri sanat, bilim, sanayi, belgesel gibi alanlarda etkili bir şekilde kullanılan fotoğrafçılık şimdilerde yaşamın bütün alanlarını etkisi altına almış durumdadır.

Analog fotoğraf teknolojisinin kitlesel olarak yayılması yeni fotoğrafçılık kavramıyla ifade edilmiştir (Bate, 2013:182). Teknik, ideoloji ve biçimin belirleyici olduğu yeni fotoğrafçılıkta 
gerçekliğe duyulan aşırı ilgi bakışa özgü örtüyü ortadan kaldırmış ve gözün gördüğü keşfetme alanı genişlemişti ancak bakışın yanılsama ile ilişkisi varlığını sürdürmekteydi (Moholy, 1939:165). Bakışa özgü gerçeklik imge, düşünce, fantezi ve sırdan bağımsız değildi. Doğrudan fotoğraf diyebileceğimiz bakışa özgü yanılsamalı fotoğraflarda gündelik yaşamda gözden kaçmış olan zihinsel süreçlerin belirgin olduğu fotoğraflar çekilmekteydi. Çekim esnası ve çekim sonrası manipülasyonun tamamen reddedildiği bu fotoğrafta yanılsama gerçeklikle var olan bağlantısını sürdürmekteydi (Değirmenci, 2016:72). André Bazin fotoğrafi diğer görsel sunumlara nazaran doğası gereği nesnel karakteri yüzünden nevi şahsına münhasır bir araç ve yeniden üretimden daha farklı biçimde insan etkisinin az olduğu mekanik bir süreç olarak ifade etmiştir (Bazin, 1960: 4-9). Bununla birlikte Bazin fotoğrafta farklı illüzyonların görsel doyuma yol açtığını da düşünmektedir. Jonathan Friday, Bazin'in fotoğrafa ilişkin yaklaşımını ontolojik gerçeklik düzleminde değil de fotoğrafın kişilerin alg1 ve psikolojilerinde nasıl öznel bir bilinç oluşturduğu anlamında değerlendirmenin gerekliliğini vurgulamaktadır (Friday, 2005:346-348). Bazin için fotoğraf, çekimi yapılan şeyin mevcut durumunun uzantısı olarak görülür ve dolayısıyla gerçekliğin yansıması ve bilince bağlı olarak gerçekliğin yanılsaması fotoğrafin gerçekliğini oluşturmaktadır.

İnsanların her tarafı çeşitli fotoğraflarla veya fotoğraf çeken kişilerle kuşatılmış durumda. İnsanlığın büyük bir kısmı mutlaka her gün fotoğraf çekmektedir. Bu durum fotoğrafın gündelik yaşantımızın bir parçası olduğunu göstermektedir (Bate, 2013:12). Bu fotoğraflar ve fotoğraf çeken kişiler insanların rızasını almadan rahatlıkla her yere sirayet edebilmektedir (Barthes, 2016:28). Yaşantımızın bütün kademelerinde kitlesel yeniden üretimin aracısı olarak karşılaşılan fotoğrafların insanlarda belirli bir bilinç ve etki uyandırmadığı iddia edilmektedir (Bate, 2013:49). Çeşitli teknolojilerle mütemadiyen seri şekilde üretilen fotoğraflar Barthes için benimsenmeyen fotoğraflar kategorisine girer ki böylesi fotoğraflarda anlamı ve gerçekliği yakalayabilmek fazlasıyla güçtür (Palal1, 2017:87). Moholy Nagy geleceğin cahillerinin okuma yazma bilmeyenler değil, fotoğrafin anlamını sökemeyenler ve fotoğrafı okuyamayan kişiler olacağını iddia etmiştir. (Moholy-Nagy, 1927:257). Ancak bu cehalet hem fotoğrafi çeken kişinin hem de fotoğrafa bakan kişinin cehaletidir. Baktığı fotoğrafi anlamayan kişiler olacağı kadar ne için fotoğraf çektiğini bilmeyen ve çektiği fotoğrafı okuyamayanlar da olacaktır. Bu durum fotoğrafın düşünceden ve gerçeklikten bağımsız hale geldiğinin ispatıdır.

Fotoğraf görüntülerine her yerde rastlamanın ve herkesin fotoğraf çekerek kendisini fotoğrafçı ilan etmesinin estetik ve ahlaki sorunlar ortaya çıkardığı bir dönemde yaşadığımız iddia edilmektedir (Sontag, 2011:1). Etrafımızda çok fazla miktarda fotoğraf görüntüsü ve ellerinde fotoğraf makinesiyle dolaşan insan var. Aygita bağlanmak, tekniğe boğulmak ve fotoğrafik saldırganlık mevcut fotoğrafçılığın en büyük problemlerindendir (Palalı, 2018:68). Flusser paleolitik çağda yeryüzünde açlığını gidermeye çalışan eli baltalı insanların davranışlarıyla mevcut dünyanın fotoğrafçıları arasında fark olmadığını söylemektedir (Fluser, 2009:33). Aynı biçimde Yurdalan, İlk çağ avcıları ile modern avcılar arasında fark olmadığını avcılığın kültürel anlamda anlam değişikliğine uğrayarak fotoğraf çekme işine evirildiğini söylemektedir (2007:21). Fotoğrafçıların ve fotoğrafların her tarafa yayılmış olması etik duyarlılığı fazlasıyla zayıflatmaktadır.

"Her şeyin görüntüye dönüştürüldüğ̈̈ yalnızca görüntülerin var olduğu, üretilip, tüketildiğ $i$ görüntüler sağanağı içinde yaşıyoruz (imaj repertuvarı). Görüntülerin zevkin vücuda gelmesinde zorunlu bir unsur olması sonucunda, insan doğası-ve arzusu-gerçekdışı bir kavrayışa ulaşmıştır: 'pornografikleşmiş imajlar...' Bu kavrayışın sebebi görüntülerin fütursuz olmasından değil artık her şeyin imajla ifade ediliyor olmaslyla ilgilidir.” (Palal1, 2017:99).

Fotoğrafı çeken gözün doymak bilmeyen arka planında dikkat edilmesi gereken bir sürü husus bulunmaktadır. Fotoğrafik görüntünün her şeyden evvel kendi nevi şahsına münhasır özgünlüğü ve etiğinin analog fotoğrafçılık döneminde mevcut olduğu düşünülmektedir. Fotoğrafik görüntüye sahip olmak dünyaya ve dünya gerçekliğine ulaşmanın bir aracıyken artık dijital fotoğrafta 
neye hizmet ettiği belli olmayan bir yola sapıldığı iddia edilmektedir. Analog fotoğrafta bir şeyi fotoğraflamak onu ele geçirmenin bir yolu, imgelemenin gücü, düşünmenin çok boyutluluğu, eleştirmenin güzelliği, bilmenin esrarengizliği ve nesneyle iletişim kurmanın meta aşamasıyken dijital fotoğrafta hıza kurban edilmiş görmeden bakmanın farklılaştırılmış bir formuna dönüşmüştür. Dijital fotoğraflar düşünmeye ve akıl yürütmeye imkân tanımamaktadır (Freund, 2016:189). İyi fotoğraflar çekme sevdasına düşen fotoğraf uğraşçıları fotoğraflarını çektikleri kişilerin poz vermelerini sağlamak için gerekirse para teklif ederek poz vermelerini istemekte; görüntü elde edebilmek için törenlerin tekrarını talep etmekte; kutsal şeylerin, dini ritüellerin mahremiyetlerine müdahale etmektedir. İnsanların hayatlarına düşüncesizce müdahale ederek elde edilen görüntüler sadece fotoğrafı kimliksizleştirmemekte var olan simgesel düzeni de bozmaktadır. Dijital fotoğraf dünyasında öylesine fazla fotoğraf çekilmektedir ki çekilen bir eserdeki taşın yıpranmasından ziyade deklanşöre basan parmağın yıpranması daha önemli hale gelmektedir. İnsanları en mahrem en rahatsız edici biçimde fotoğraflamanın büyüleyici ve estetik hiçbir yanı bulunmamaktadır. Zaten dijital fotoğrafın insanları hayal kırıklı̆̆ına uğrattığı ve fotoğrafın büyüsünü ortadan kaldırdığı ileri sürülmektedir (Değirmenci, 2016:8). İlk dönem fotoğrafçıları kaybolmakta olan bir dünyanın fotoğraflarını elde etmenin derdine düşmüşken dijital dönem fotoğrafçıları ise dünyanın yok oluşunu hızlandırmaktan başka bir iş yapmamaktadır. $\mathrm{Bu}$ insanlar sürekli parça toplama arzusundaki koleksiyoncular gibi her şeyi çekme, biriktirme arzusundadır. Bu fotoğrafçıların koleksiyonculardan fark1 şudur: Koleksiyoncular bütün parçaları biriktirirmeyi tercih edereken, fotoğrafçılar sürekli çektikleri fotoğrafları ekrandan görüp silmeyi yeğliyorlar. $\mathrm{Bu}$ türden fotoğraflar her yerde rastlanabilen, paylaşılabilen, değer tanımlamasından uzak, herhangi bir cazibe taşımayan basit nesneler olarak değerlendirilmektedir (Sontag; 2011:98).

Fotoğraf makinesinin deklanşörüne bastığımız zaman gerçekliği oluşturan şeyin zihinsel bir imge faaliyeti değil önceleri optik kimyasal şimdilerde optik elektronik bir süreç olduğu kabul edilmektedir. Yani fotoğraf makinesi gerçekliğin oluşumunda zihinsel süreçlere daha baskın haldedir. Allan Sekula gerçekliğin asla fotoğraf cihazıyla elde edilemeyeceğini ve gerçekliğin fotoğraf makinesi tarafindan farklı hale getirildiğini iddia etmektedir (Sekula, 1984:1793-1983). Sekula'nın bu söyleminde analog fotoğrafçılığın gerçekliğinin yanılsamayı azaltmasına bir serzeniş vardır. Ancak analog fotoğrafçılıkta gerçekliğin yanılsamayla ilişkisi söz konusudur. Tarafsız olduğu iddia edilen objektif görünen gerçeklik ötesinde bir sürü yanılsama yaratabilmektedir. Elde edilen fotoğrafik görüntüler hem fotoğrafı çeken kişinin görme biçiminden, hem objektifin özelliğinden hem de çekilen nesnenin özelliğinden dolayı mutlak gerçeklikten ziyade yanılsamalı gerçeklikleri gösterebilmektedir. Ancak gelinen yeni post fotoğrafik süreçte gerçeklik tamamen farklı bir formata sokularak gerçekliğin öznel yanı ortadan kaybolmaktadır. Halbuki fotoğrafik gerçekliğin nesnel tarafı soğukken, öznel tarafı sıcaktır (Bate, 2013:86). Mevcut dijital dünya fotoğrafa bakma şeklimizi de değiştirmiştir. Fotoğrafik görüntünün bütünsel ve apaçık olduğu bir dünyada yetişen nesil analog fotoğrafin doğasında barındırdığı yanılsamalı gerçekliği önemsememektedir. Savedoff’a göre şimdi ve sonraki nesil fotoğrafik gerçekliği gizemli şeyleri ortaya çıkaran bir imge mücadelesi değil, birer yap1 ve kurgu olarak algılayacaktır (Savedoff, 2018:166). Dijital fotoğrafçılıkta fotoğraf özünü ve gerçekliğini kaybederek başka bir şey olmaya başlamıştır; bundan sonra ismine fotoğrafik görüntü diyemeyeceğimiz farklı bir görüntü zamanına geçilmiştir (Palalı, 2017:99). Bu görüntü zamanında fotoğrafik gerçekliğin insani tarafı ise tamamen yok olmuştur.

\section{2-2 Fotoğraf Sonrası Fotoğraf Dönemi}

Fotoğrafin dijital teknolojilerin egemenliğine bırakılarak bakışa özgü gerçekliğin devre dışı bırakılması yeni gerçeklik kavramıla ifade edilmektedir (Bate, 2013: 101). Aynı şekilde fotoğrafın önceden belirlenmiş kodlara göre oluşturulduğu dijital dönem apaçık gerçeklik nosyonuyla da açıklanmaktadır (Savedooff, 2018:166). Apaçık gerçeklik ve yeni gerçeklik kelimeleri kurgulanmış görüntüyle ilişkili olduğu için yanılsama fotoğrafta yok olmaktadır. Fotoğrafik gerçeklikte gerçekliği belirleyen şey saf gerçeklik olmalıdır ki bu gerçekliğin yanılsamalarla yakın ilişkisi vardır. Ancak 
yeni fotoğrafik gerçeklik saf gerçekliği devre dışı bırakarak kendi belirlediği yeni gerçekliği baskın hale getirmiştir. Dijital fotoğrafçılı̆̆ın analog fotoğrafa nazaran daha zahmetsiz olması fotoğrafın emek yönüne ve saf değerine zarar vermektedir (Çakar, 2015:81). Fotoğrafın bütünsel olarak gerçek hale getirilmesi inandırıcılığını kaybetmesine yol açmıştır. Sayısal işlemlerle görüntü haline gelen gerçeklik artık temsilinden uzaklaşarak farklı bir hal almıştır. Bu durumda fotoğrafa ilişkin anlam ve gerçeklik ise düşünce ile bağını koparmıştır.

Fotoğrafın analog mantıktan dijital mantığa geçişi post fotoğrafçılık olarak da ifade edilmektedir (Robins, 1992). Post fotoğrafik çağ, fotoğrafin anlamını ve doğruluk değerini değiştirmiştir. (Mitchell, 1992:225). Mitchell, analog fotoğrafların fotoğrafın doğasıyla tutarlı olduğunu, gerçekliği temsil ettiğini ancak dijital fotoğrafın fotoğraftan farklı bir görüntü sunduğunu, tartışmalı ve farklı bir gerçekliğe gönderme yaptığını belirtmek için post fotoğrafik kavramını kullanmıştır. Bilgisayar sistemlerinin fotoğrafik görüntüdeki baskın durumu süper gerçeklik söylemiyle de açıklanmaktadır (Currie, 2018:316; Sontag, 2011:115). Bilgisayar sistemlerinin fotoğrafa uyarlanması farklı bir fotoğrafik döneme geçişe yol açmıştır. Önceleri gerçekliği yeniden üretme becerisine sahip olan fotoğraf, insan ile yakın ilişki içerisindeki bir medyumdu. Şimdilerde fotoğraf güncel biçimiyle insani özellikleri aşan/yok sayan ve her şeyi görünür kılan bir dijital gerçekliğe yani meta gerçekliğe dönüştüğünden fotoğrafin insan ile ilişkisi ortadan kaybolmuştur. Dijital kodlar temelde görüntülerin daha gerçek hale getirilmesi anlamını taşımaktadır ki bu gerçekten daha gerçek olan görünümün bütünsel gerçeklik görünüm kazanmasıyla ilişkilidir. Herhangi bir anlam ve mesaj içermeyen bu kodlar (Frosh, 2003:74) fotoğrafın gerçekliğini tamamen değiştirmiştir.

Mevcut dijital teknolojilerin görüntü işlemedeki alternatifsizliği bu teknolojilerle üretilen/şekillendirilen görüntülere karşı güvensizliği ve inançsızlığı beraberinde getirmiştir (Walden, 2018:134). Dijital görüntüleme tekniklerinin kural olduğu bir dünyada gerçeklik güven ve inançla olan bağlantısını koparmıştır. Bu teknolojiler gerçekliği kolaylıkla değiştirebilmekte ve dijital anlayışa bağımlı kılabilmektedir. Fotoğraf çekme işleminin analog işlemlerden kopartılıp matematiksel kodların himayesindeki dijital işlemlere geçmesi fotoğrafta güveni yok etmiştir. Elde edilen fotoğrafın gerçekliğinin görülen cisimden daha gerçek olması fotoğraf gerçeklik ilişkisini sorunlu bir hale sokmuştur (Ertuğ, 2010:119). Dijital fotoğrafçılık düşünce ile bağlantıy1 kopardığından önceleri değer taşıyan imgesel dirençler devre dışı kalmıştır (Currie, 2018:314). Lev Manovic dijital fotoğraf dönemini, fotoğraftan sonraki fotoğraf kavramıla açıklamaktadır. Manovic'e göre fotoğrafın doğal yapısının değiştirilerek farklı bir görüntü formatına sokulması-yani milyonlarca bitlik elektronik matematik verilerine dönüşmesi-fotoğrafin doğasını bozmuştur (Manovich, 1995).

Analog fotoğrafta görüntünün meydana gelmesi araca özel kimyasal ve elektronik işlemlerin işbirliği ve bütünleşmesi varken; dijital fotoğrafta ise ayrı, ölçülebilir, bağımsız ve tamamen yeniden üretilebilir nitelik taşıyan çeşitli sayısal işlemler söz konusudur. Bu durumda Baudrillard'ın fraktal kavramını dikkate almanın faydalı olacağı düşünülmektedir. Çünkü Baudrillard dijital teknolojilerde fraktal gerçekliğin en küçük parçasının bile bütünsel gerçekliği temsil ettiğini ve dijital teknolojileri kendi içerisinde bağımsız, işlenebilir ve kodlanabilir çıktılar olarak görmektedir (Baudrillard, 2005:100). Analog fotoğrafta fotoğrafi meydana getiren unsurlar, parçacıklar yani kimyasal süreç bileşenleri kendi başlarına herhangi bir anlam ifade etmezken dijital fotoğrafta fotoğrafı meydana getiren unsurlar bütüne gönderme yapan ve bütünü tanımlayan bilgilerdir. Bu durum Mika Elon tarafindan metadata kavramıla ifade edilmiştir.

Dijital fotoğrafçılıkta önceden kodlanmış sahne ve mekân ayarlı bilgisayar sensörlerinin mantığını görebilmekteyiz (Bate, 2013:11). Fotoğraf makinesinde her şey önceden matematiksel kodlarla belirlendiği için kimsenin kötü/başarısız fotoğraf çekmesi mümkün değildir (Freund, 2016:184). Artık fotoğraf çekmeden önce hazır kalıp modülasyonlardaki seçeneklere göre gerçeklik 
farklılaştırılabilmektedir. Mesela manzara fotoğrafi çekeceğiniz zaman gökyüzünün olduğundan daha mavi gözükmesi, orman görüntüsünün daha yeşil çıkması, daha canlı renkler, daha yumuşak renkler, çeşitli filtre efektleri ve önceden belirlenmiş teknik tasarım fotoğraflar vb mümkün olabilmektedir. $\mathrm{Bu}$ durum gerçekliğin yanılsama lehine avantajlı durumundan tamamıla yanılsamanın yok olduğu gerçekliğe ulaştığımız fotoğrafçı1lı̆a işaret etmektedir. $\mathrm{Bu}$ türden fotoğraflar otomatik bakma eğiliminin olduğu fotoğraflar olarak değerlendirilmektedir. Hatta artık bakmaya bile gerek yoktur, çünkü fotoğraf makinesi bizim yerimize görmektedir (Freund, 2016:181). Dijital fotoğrafçılıkta fotoğrafın önceden hazırlanmış kodlarına uygun biçimde imajlar görülmektedir. Bu kodlama sadece bakmaya yönelik kodlamaları değil aynı zamanda anlama yönelik kodlamaları da kapsamaktadır (Bate, 2013:32). Bilgisayar teknolojileriyle üretilen imajlar analog imajlardan farklıdır; analog fotoğrafta bakma ve görme pratikleri dijital fotoğrafta sadece bakma ile sınırlandırılmıştır. Bu durum algının doğasını değiştiren ve fotoğrafik gerçekliği farklılaştıran bir dönüşümdür.

\section{2-3- Fotoğrafta Manipülasyonun Etkisi}

Fotoğraf teknolojisi gerçekliği değiştirmede muktedir hale gelmiştir. Bu değiştirmeler çeşitli objektif seçimleri, pozlama ve alan derinliğiyle elde edilen nesnel değişikliklerden çok fotoğrafın düşünce ile var olan ilişkisini dolayısıyla fotoğrafın anlamını değiştiren bir gerçekliği ifade etmektedir. Negatif baskı üzerinde bile rötuş yapma uygulamasının ortaya çıkması ve yaygınlaşması fotoğrafa olan saygıyı ve ilgiyi azaltmış ve fotoğrafın beğeni düzeyi gerilemeye başlamıştır (Benjamin, 2018:17; Leslie, 2019:108). Dijital fotoğrafçılığın manipülasyona kolaylık sağlayan olanakları fotoğraf ve gerçeklik arasındaki bağlantıyı sorunlu hale getirmiştir (Savedoff, 2018:164). Düşüncenin yerini alan teknoloji ile birlikte fotoğrafın gerçekliğine var olan inanç yok olmakta; elde edilen görüntüler daha az anlamlı ve temsilsiz bir hal almaktadır. Dijital tarafindan çepeçevre kuşatıldığımız dünyada dijitalin belirgin kıldığı görme şekli fotoğraflara nasıl bakmamız ya da bakmamamız gerektiğini belirlemiştir. Çünkü dijitalleşme kural olarak kendisini hegemon kılmıştır. Dijital fotoğrafçılık fotoğrafin hem çekim esnasında manipülasyonunu hem de çekim sonrasında çeşitli teknolojilerle manipülasyonu daha kolay hale getirmiştir (Yaykın, 2017:37). Gerçeklik bağlamında konu ele alındığında gerçekliğin aşılıp geçilmiş olması fotoğrafik görüntüye var olan inancı da sarsmıştır.

"Dijital manipülasyon uygun yazılımla göreceli olarak daha hızlı ve kolaydır ve manipülasyon görsel olarak sınırsızdır. Hatlar yeniden şekillendirilebilir, biçimlendirilebilir ya da istenirse yerinden kaldırılabilir; farklı kaynaklardan görüntüler birleştirilebilir ya da karıştırllabilir ve manipülasyon yüksek bir beceriyle yapıldı̆̆ zaman görsel olarak fark edilemez. Sonuç olarak kendimizi yalnızca bir şekilde üzerinde oynanmış fotoğraflarla daha da çevrili bir halde bulmakla kalmayız ama yanı zamanda değisstirilmiş fotoğraf ile doğrudan fotoğrafi arasindaki farkı söylemek gittikçe olanaksızlaşır. Dijitalleşen ve değiştirilen fotoğrafin sayısı artmaya devam ettikçe ve daha çok insan, şipşakları üzerinde bilgisayarda oynadıkça, bir fotoğrafla karşılaşıtığımızda sahip olduğumuz beklentiler de değişime uğrar" (Savedoff, 2018:165).

Dijital fotoğrafin ortaya çıktığı dönemler dijital fotoğraf görüntüsü üretim sistemlerinin yaygın hale gelmesiyle birlikte fotoğraf-gerçeklik ilişkisinin bozulacağı ve fotoğrafin farklı bir görüntü formatına dönüşeceği düşünülmekteydi. Vilém Flusser fotoğrafın maddilikten uzaklaşarak elektromanyetik alana geçmesiyle kimyasını terk ettiğini ve artık kâğıtlar üzerinde değil de ekran üzerinde göründüğünü ve bu durumun kültürel bir dönüşüm olduğunu düşünmektedir (Akt. Değirmenci, 2016:195). Dijital fotoğrafta çekim esnasında gerçekliği manipule eden prodüksiyonlar analog fotoğrafa oranla daha üst seviyelerde yapılmaktadır. $\mathrm{Bu}$ durum Ritchin tarafından simülasyonun gerçekliğin yerini alması şekliyle yorumlanmışsa da (Ritchin, 1999) asıl tehlike bütünsel gerçekliğin simülasyondan daha başarılı bir biçimde gerçekliği yok etmesidir. Optikkimyasal süreçlerle elde edilen analog fotoğraf görüntüleriyle insanın hayal gücü arasında güvenilen 
bir bağ varken optik-elektronik-bilgisayar süreçlerle elde edilen dijital fotoğraf görüntüleriyle insanın hayal gücü arasındaki bağ yok olmuştur. Dijital fotoğraflar yalanın gerçek gözükmesini, çirkinin güzel hale getirilmesini, yanlışın ise doğrulamasını yapmaktadır (Berger, 2017:89).

\section{2-4 Fotoğraf ve Nedensellik İlişkisi:}

Dijital fotoğraf tekniklerinin 2000'li yıllardan itibaren gelişerek yeni bir kültür halini alması ve bu kültürün giderek yaygınlaşması fotoğrafin mevcut durumunu tartışmalı hale getirmiştir. Literatürde dijital fotoğrafçılığın analog fotoğrafçılığın yerini almasıyla birlikte geleneksel fotoğrafın sonlanarak farklı bir görüntü dünyasına geçildiğine dair fikirler ileri sürülmüştür. Dijital fotoğraf teknolojileri analog fotoğrafçılıkta mevcut insani yönü tamamen devre dışı bıraktığ 1 için fotoğrafın temsil gücünün yok olduğu ve nedenselliğin ortadan kalktığı iddia edilmektedir (Değirmenci, 2016:188-189).

Fotoğraf makinesi aracılığıyla insan çevresindeki şeylere neden atfetmektedir (Berger, 2017:114). Bu durum analog fotoğrafçılığın doğasına uymaktadır. Yani fotoğraf makinesi hem bir fotoğraf çekmenin aracısı hem de çekilen görüntüye etki eden zihinsel düşüncenin gerçekleşme yoludur. Dijital bir fotoğraf görüntüsü nesne ile kurmuş olduğu ilişki bağlamında ele alındığında bu görüntünün fotoğraf olduğunu söyleyebilmek çok güçtür; normalde dijital fotoğrafta sensör üzerine kaydedilen veri, algoritmik olarak tasarlandığı için elde edilen görüntü fotoğraf haricindeki bir şeyi göstermektedir ki bu durum özne ile nesne arasındaki nedenselliğin kaybolduğunun ispatıdır.

Analog fotoğrafçılıkta saklama ile görüntü yani negatif ile baskı arasında nedensel bir ilişki söz konusudur; ancak dijital kültürde nedensellik ortadan kaybolmuş ve algoritmik anlamda dijital bir iş süreci ortaya çıkmıştır (Røssaak, 2011:193). Analog fotoğrafta fotoğrafın çekildiğinin en önemli belirtisi saklama ile görüntü arasında nedenselliğin var olmasıdır (Değirmenci, 2016:217). Dijital fotoğrafçılıkta nesnenin nitelikleri önceden belirlenmiş aritmetik kodlara göre oluşturulmakta ve karşılaşma anında görünen nesnenin ışık parçacıkları binary ( 0 ve 1$)$ sisteme göre dijital hale getirilmektedir. Dolayısıyla analog fotoğrafta önem kazanmış olan karar anı, gebe an, bağımsız imgelem, estetik bakış, öznenin yok oluşu, yaratıcılık gibi nosyonlar dijital fotoğrafta herhangi bir anlama ve değere karşılık gelmemektedir. Çünkü dijital fotoğrafçılıkta yaratıcılık süreci önceden belirlenmiş hazır kalıp kodlar ve çekim esnasında oluşan sayısal aktarımların bir çıktısını vermektedir. Dijital veriler gerçek yaşamdaki referanslardan bağımsız durumdadır. Dolayısıyla fotoğrafta yaratıc1lıktan dijital fotoğrafta bahsedilmesi mümkün değildir.

“... analog fotoğraftaki nedensellik nosyonunun dijital fotoğrafta ortadan kalktı̆̆ öngörülebilir. Bir dijital fotoğraf makinesinin ekranında az önce çektiğimiz bir fotoğrafa bakarken, bu imgenin aynen analog fotoğrafta olduğu gibi görünen nesnelerle ontolojik bir iliş̧ki içerisinde olduğunu söyleyebiliriz. Ancak durum hiç de böyle değildir. Aslında elimizdeki dijital makinenin sensörü içerisindeki yazılımın bu sensör üzerine kaydedilen enformasyonu bizim fotoğraf olarak algılayabileceğimiz bir biçime çevirdiğini düşünürsek durum biraz daha netleşecektir" (Değirmenci, 2016:213).

Sayısal teknolojilerle üretilen dijital fotoğraflar sanal temsiller oluşturmaktadır. Dolayısıyla analog fotoğrafta karşılaştı̆̆ımız mekânsal ve zamansal bağlilıklar ile nedenselliği dijital fotoğraflarda görmemiz mümkün değildir. Algoritmik mantıkla ham ve kodlanmış datalardan üretilen dijital çıktılar insan faktörünün minimum hale getirildiği ve düşüncenin yok sayıldığı yeni bir görüntü teknolojisidir. Bu teknolojilerde nesnelere algılamada belirgin olan gerçekliğin insani yönü yok edilerek sayısallaştırılan ve manipüle edilen gerçekliğin fraktal boyutu ortaya çıkmaktadır. Değirmenci (2016:22-224), dijital fotoğrafların analog fotoğraflardan farklı olduğunu, analog fotoğrafa özgü nitelikleri taşımadığını (belirtisellik, nedensellik, yanılsama gibi), temsil noktasında dijital fotoğraflara yeni temsiller bulunması gerektiğini söylemektedir. Negatif şerit ve yanılsamanın yok olduğu dijital fotoğrafçılıkta görüntünün oluşabilmesi için nesnenin gerçekliğine ihtiyaç duyulmamaktadır (Baudrillard, 2012:19). Çünkü nesne artık gerçeklikten bağımsız biçimde 
istenildiğinde üretilebilir bir dijital formattır. Önceleri bir şeye tanıklık eden fotoğraf makinesi çekimi yapılan şeyle nedensel bir ilişki kurabiliyorken artık bu nedensellik ortadan kalkmıştır.

\section{3-Gerçeklik İnsan İlişkisi}

\section{3-1 Fotoğrafta İnsani Niteliklerin Durumu}

Fotoğrafların gerçekliği gösterdiğine ilişkin yaygın söylem doğru değildir (Walden, 2018:22). Fotoğraf, gerçekliğin herkesin baktığı anda farklı bir biçimde yorumladığ 1 şeydir (Barthes, 2016:122). Haluk Uygur da, fotoğrafın gerçeği yansıtmadığını iddia etmektedir (Akt: Ökten, 2013:142). Bir fotoğrafta yanılsama ve gerçeklik bir arada olmalıdır (Berger, 2017:166). Çünkü gerçeklik düşünceden bağımsız değildir ve gerçeklik öznelliğe gönderme yaparak yanılsamayı yüceltmelidir. Fotoğrafta kesinlikle gerçekliği bulduklarını iddia edenler hazır kalıp bütünsel gerçekliğe bakmaktan başka bir şey yapmamaktadır. Yanılsama barındıran gerçeklik düşünsel hale gelmekte ve kişisel imgelerle gerçeklik farklı bir anlama sahip olmaktadır. Böylesi bir anlamın oluşabilmesi yönlendirmelerden bağımsız yaratımlarla gerçekleşebilmektedir. Bunun için de önceden hazır hale getirilmiş kodlardan ziyade fotoğrafa bakıldığ 1 esnada meydana gelen imgeler belirleyici nitelik taşımaktadır. Gerçeklik görüntülerin bakılan kısmından ziyade bu görünümlerin zihinlerde oluşturduğu imge ve düşüncelerle ilgilidir. Barthes, Camera Lucida'yı tarif ederken gerçekliğin düşünce ile ilişkisini şu şekilde belirtmiştir:

“Camera Lucida: Görüntünün özü, hiçbir içtenlik olmaksızın tümüyle dışarıda, ama yine de en içteki varliğın düşüncesinden daha ulaşılmaz ve gizemli olmaktır; göstergesiz, ama her olası anlamın derinliklerini çağırır biçimde" (Barthes, 2016:125).

Roland Barthes fotoğrafin insan ile olan ilişkisini kapalı kuvvetler alanı söylemiyle ifade etmektedir (Barthes, 2016:25). Ona göre fotoğrafta olduğu sanılan gerçeklik, mercek önündeki gerçeklik, başkalarının görmesi istenen gerçeklik ve fotoğrafçının gördüğü gerçeklik yanılsama alanında mücadele etmekte ve ortaya çıkan gerçeklik mutlak anlamda yanılsamalı bir gerçeklik niteliği kazanmaktadır. Konsantrasyon, zihinsel disiplin, hassasiyet ve geometri duygusu kaygısıyla elde edilen fotoğraflarda zihinsel bir emek söz konusudur (Davies, 2018:203). Ancak dijital fotoğrafçılıkta ortaya çıkacak gerçeklik önceden hazırlanmış kodlar tarafından belirlendiği için zihinsel emek gerçekleşmemektedir. Önceden kodlanmış teknik yapılanma görüntülerin her yanımızı kuşattığ okuyamama oranının artmasıdır (Ökten, 2011:74). Barthes, gerçeklik yanılsama ilişkisinde yanılsamanın devre dışı bırakılarak gerçekliğin egemen kılınmasını bütün görüntü olarak açıklamaktadır (Barthes, 2016:26). Fotoğrafin noeması (yani özü) yanılsamalar barındırmalıdır. Hazır kalıp hale getirilmiş ve gerçekliğin öznel yanının yok edildiği fotoğraflarda fotoğrafın derinliklerine inilmemekte, öteki tarafı görme çabası gösterilmemekte yani fotoğrafın arka yüzüne bakılmamaktadır (Barthes, 2016:118). Bu türden fotoğraflar gerçekliğin insani tarafinın yok edildiği fotoğraflardır. Fotoğraf gerçekliği sadece insani niteliklerin barındırdığ gerçeklikler derecesinde göstermelidir. Fotoğraf makinesinin görmüş olduğu doğa ile insanın görmüş olduğu doğa farklıysa bu durum gerçekliğin aşılıp geçildiğini göstermektedir (Freund, 2016:176). Mevcut haliyle fotoğrafik görüntü fotoğrafçının zihinsel hallerini aşan ve dijitalitenin belirleyici olduğu bir sürece yani ayrıntının belirgin olduğu bir teknolojiye gönderme yapmaktadır (Walden, 2018:131). Handan Tunç, analog fotoğraftan dijital fotoğrafa geçişle birlikte gerçeğin izlerinin sonsuza dek bir daha bulunmayacak şekilde kaosta yitip gideceğine dair endişe duymaktadır (Akt: Yaykın, 2017:159). Dijital fotoğraf makinelerinde önceden hazırlanmış sayısal kodların belirlemiş oldukları görüntü formatları ve süreçleri belirleyicidir. Gerçeklik matematiksel kodlara göre oluşmakta; görünen ve algılanan gerçekliğin haricinde farklı bir gerçeklik görsel hale getirilmektedir. Dijital fotoğraflar kurgulanmış fotoğraflar olduğundan bunlarda sadece studium etkisi oluşmaktadır. Çağdaş fotoğrafların çokluğu, çeşitliği ve gerçeklik üzerindeki etkisi fotoğrafın punctum etkisini yok 
etmiştir. Kaldı ki fotoğraftaki punctum etkisi fotoğrafın çekildikten hemen sonra bakıldığı anda değil düşünülen ve beklenilen zaman diliminde ortaya çıkmaktadır.

Bir insan fotoğrafa baktığında sadece duygulanım alanı harekete geçerse (merhamet, korku, öfke, sevinç gibi) bu o fotoğrafın başarısız olduğu anlamına gelir. Fotoğrafa bakan insan duygulanım alanını aşarak çözüm bulabilmeli ve harekete geçebilmelidir (Berger, 2017:188). Dijital fotoğraflarda savaş, sefalet, açlık vb ideoloji fotoğrafları ise ne duygulanım alanına ne de aktivasyona etki etmektedir. Bu fotoğrafçılık insanı devre dışı bırakarak fotoğraf çekme eylemini farklı bir teknolojik formata dönüştürmüştür (Ökten, 2011:29). Bakma, görme, algılama, düşünme ve harekete geçmenin önemsiz hale geldiği dijital fotoğrafçılıkta insani nitelikler devre dışı bırakılmıştır. Dijital kuşağın yapmış olduğu şey dijital bir dünyada sistem tarafindan sunulan teknolojik imajları içerimleyerek düşünmekten uzak durmaktır.

Geleneksel gerçeklik kavramının düşünce ile yakın ilişkisi vardır. Analog fotoğrafta fotoğrafi çeken kişi düşünceyi ve düşünmeye bağlı pratikleri göz önünde tutarak harekete geçmekte ve fotoğrafta anlam oluşturmaktadır. Fotoğraf ve düşünce arasında ilişki kurulmadığı sürece fotoğrafın gerçekliğine ilişkin tartışmalar önemsiz kalmaktadır (Ökten, 2013:127). Duygu, düşünce, estetik kayg1, imge, yanılsama $\mathrm{vb}$ insani nitelikler fotoğrafik gerçekliğin tamamlayıcı öznel yanlarıdır. Dijital fotoğraf gerçekliğin insani yönünün devre dışı bırakıldığı kurgulanmış, kodlanmış ve önceden inşa edilmiş farklı bir gerçekliği işaret eden ve içerisinde şüphe barındıran post fotoğrafik bir süreçtir (Trachtenberg, 2008:1111-1132). Gerçekliği geleneksel tanımından ayırarak farklı bir tanımlama alanına koyarsak o zaman dijital fotoğrafçılığ ilişkilendirebiliriz. Ancak analog fotoğrafın gerçekliğini açıklayan otantisite, belirtisellik, kanıt, şeffaflık, temsil, yanılsama, kompozisyon, doğrudanlık gibi kavramların dijital fotoğrafçılıkta da telaffuz edilmesi aslında gerçekliğin geleneksel anlamının devam ettiğini göstermektedir (Değirmenci, 2016:194).

\section{3-2 Yanılsama ve Fotoğraf İlişkisi:}

Analog fotoğrafta elde edilebilecek fotoğraf sayısı kısıtlı olduğu için fotoğraf çeken kişi çekim yapmadan önce düşünmek zorundayd. Buna fotoğrafik düşünce denilmektedir. Bu düşünme biçimi fotoğraf çekiminin öncesini, fotoğraf çekim anını ve fotoğraf çekildikten sonraki zaman dilimlerini kapsamaktadır. Ancak dijital fotoğrafta çekilebilecek fotoğraf sayısı ile ilgili sınırlandırmalar söz konusu olmadığından fotoğrafik düşünceye ihtiyaç duyulmamaktadır. Fotoğrafçı, önceleri fotoğraflamaya değdiğini düşündüğü bir hadiseyi ya da gözüne çarpan kaydedilmeye değer bir nesneyi görüntü formatına sokmakta ve o fotoğraflara değer vermekteydi. Şimdilerde ise çekilen fotoğraflarda sayı olarak herhangi bir kısıtlama olmadığı için sürgit fotoğraflar çekilmekte ve bu fotoğraflar herhangi bir anlam taşımamaktadır (Berger, 2017:36).

Güncel fotoğrafların bir olaya ilişkin anlamdan ve yanılsamadan yoksun görünümler dizisini insanlara aktardığı iddia edilmektedir. Bu görünüm dizilerinin etkileri sadece şok derecesinde kalmaktadır. Fotoğrafın dijital teknoloji ile birlikteliği neticesinde sayısız miktarda fotoğraf çekme olanağı doğmuş ve sayısal temelli yeni bir görüntü formatı ortaya çıkmıştır. Bu görüntü formatında imaj ile düşünce bağı koptuğundan toplumsal yaşamı göstermeye muktedir en önemli fotoğraflar bile ekran üzerinden kayıp gitmektedir. Dahası bu fotoğraflara bakılsa bile fotoğraflar gerçeklik temeli olmadıkları için insanlar üzerinde iletişim etkisi oluşmamaktadır. Konuşabilmenin sessiz yolu olarak bilinen fotoğraflara artık bir şey anlatmaları için izin verilmemektedir (Çakar, 2015:89-90).

Benjamin için fotoğraf çıplak bakışla elde edilemeyen çeşitli katmanlardan oluşmuş olan ve sadece teknoloji marifetiyle fark edilebilen bir gerçekliği ortaya çıkartır ki bu durum fotoğraf çeken kişinin bilinci dışında meydana gelmektedir (Leslie, 2019:27). Ancak teknolojinin bilinci devre dış1 bıraktığ 1 iddia edilmiş olsa bile fotoğrafik beklemenin bilinçle yakın ilişkisinin olduğu göz önünde bulundurulmalıdır. Çıplak gözle ve objektiften bakarak görülen gerçeklik belirli bir alan derinliği içinde, fotoğrafı çeken kişi ile bir mesafe arasındaki mekânda bulunabilmekte ve fotoğrafın 
deklanşörüne basıldığında hala orada olabilmektedir. Lakin belirli bir süre sonra fotoğraf görüntüsüne bakıldığında fotoğrafı çekilen şey görülmeyebilmektedir. Kesin ve mutlak bir biçimde oradayken fotoğraf çekildikten sonra gerçeklik fotoğrafta yok olabilmektedir. Barthes bu durumu interfuit kavramıyla açıklamaktadır. Aynı biçimde çıplak gözle ve objektiften bakıldı̆̆ında görülmeyen bir gerçeklik de daha sonra ortaya çıkabilmektedir. Fotoğrafı çekilen şeyin fotoğrafın banyo edilmesinden sonra yok olması ve çekim esnasında yok olan bir şeyin fotoğrafın banyo edilmesinden sonra ortaya çıkması analog fotoğrafın özelliklerindendir. Fotoğraf çekim esnasında görünmeyen bir şeyin daha sonra gözükmesi veya görüldüğü zannedilen bir şeyin ortadan kaybolması fotoğrafin temsiline ve özüne ilişkin bir durumdur (Palal1, 2017:24) Görünmeyen şeylerin fotoğrafta görünür olduğu ya da görünen şeylerin kaybolduğu duruma analog fotoğrafta sıklıkla rastlanılmaktadır (Berger, 2017:197). John Berger için izleyicinin imgelemini allak bulak eden bu fotoğraflar değerli fotoğraflardır. Bu fotoğraflarda fotoğrafi çeken kişinin algıladığı gerçeklik ile o gerçekliğin görünümsel durumu uyumsuz olabilmektedir (Price, 2014:19). Analog fotoğraf gördüğümüzden daha fazlasını veya daha eksiğini gösterebilen bir fotoğrafken dijital fotoğraf görünen şeyin hep daha fazlasını, bütününü ve ayrıntısını göstermektedir.

Analog fotoğraflarda hangi görme biçimiyle bakılırsa bakılsın fotoğraf yanılsamalar barındırmaktadır. Bu türden fotoğraflar gördüğümüz şeyin aslında bakılan şey olmadığını göstermesi açısından önemlidir. Çünkü analog fotoğrafta çekilen bir fotoğraf görüntüsüne hemen bakılamamakta fotoğrafı görmek için çeşitli işlemlere ihtiyaç duyulmaktadır. Ancak dijital fotoğrafta fotoğrafın çekildiği an ile fotoğrafa bakılan an arasında zaman farkı bulunmamaktadır. Roland Barthes çekilen bir fotoğrafta gözle görülmeyen şeyin daha sonra gözükmesini veya gözle görüldüğü iddia edilen şeyin daha sonra fotoğrafta görünmemesini skandal etkisi kavramıla da ifade etmektedir. Gözükmeyen şeylerin fotoğrafta gözükmesi gerçekliğin açığa çıkması ile açıklanırken görülen şeylerin saklanması gerçekliğin yok olmasıyla ifade edilmektedir.

Fotoğrafı gerçek kılan şey fotoğrafin maddi unsurlarının ötesinde imgeyi harekete geçiren bağımsız etkileşim durumudur (Tagg, 1988:4-5). Fotoğrafik imge ancak düşünme ve algılama sürecinden geçtikten sonra gerçekliğe dönüşmektedir ki bu gerçeklik yanılsamalar barındırmaktadır (Değirmenci, 2016:93). Ancak dijital imgede düşünme ve algılama gerçekleşmediğinden dolayı bu imgenin temsili olduğu herhangi bir gerçeklik oluşmamaktadır. Fotoğrafik gerçeklik, fotoğrafi çekilen nesne ile imge arasında kurulan yanılsama ilişkisi üzerinden tanımlanmaktadır. Değirmenci'ye göre;

"Fotoğrafik gönderge ile imge arasında, dolayısıla imge ile gerçeklik arasında fotokimyasal süreçlerle kurulan maddi bă̆ ayn zamanda fotoğrafik gerçekliğin de üzerinde yükseldiği bir temeldir" (Değirmenci, 2016:95).

Analog fotoğraf çekimlerinde özne ile muhatap olduğu nesne saniyelik dilimlerle yok olmakta (denilebilirse ölmekte), deklanşöre basıldığında nesne ve nesneyi hisseden öznel bakış devre dışı kalmakta; anlık bilinç yokluğu sonrasında imge etkisi sürmeye devam etmektedir. Dijital fotoğrafçılıkta ise tamamen bilgisayar programlama mantığına uygun milyonlarca bitlik elektronik matematik verisiyle imajlar elde edilmekte; fotoğrafı değerli kılan bilinç, düşünce, yüzleşme, yanılsama, hayal ve imge yok olmaktadır. Baudrillard bu mantıkla elde edilen görüntülere bilgisayar üretimli imgelem demektedir. Bilgisayar üretimli imgelemde çekim anı montajı, çoklu medyatik durum, kolajlar, VR, bracket, filtre vb sayısal teknolojiler analog fotoğrafta mümkün olan zaman aralığ 1 , mesafe ve yeniden canlandırmayı yok etmiş̧; imgeyi olanaklı kılan negatif şerit ve duyarlı katmanın gerçeklikle bağlantısını ortadan kaldırmıştır.

Görme nosyonu bilgi, hakikat ve gerçekliği elde etmede en üst duyu olarak kabul edilmektedir (Değirmenci, 106:158). Fotoğrafta görme kavramı ruhun gözüyle aklın ışığının birleşmesi neticesinde oluşabilmektedir. Ruhun görmesiyle aklın ışı̆̆ının birleşmesi; yanılsama, düş, kuvve, hayal, simgesellik vb kavramlara gönderme yapmakta ve gerçekliğin ancak insani niteliklerle 
örtüşmesi durumunda değer kazanabileceğini açıklamaktadır. Dijital fotoğrafçılıkta insan gözünün normal görme sınırları dışında yatan şeyler bile fotoğraf makinesi tarafindan gösterilebilmekte, çeşitli teknolojiler ile gözün göremedikleri ifşa edilebilmektedir. Dijital fotoğraf görüntüsü içerisindeki en küçük ayrıntıların bile görünmesi fotoğrafı çeken kişinin kontrolünde olmayan bir durum; fotoğrafın teknolojik özelliğinin bir çıktısıdır. Bundan böyle gözün göremeyeceği ayrıntıların ve ifadelerin fotoğraf makinesiyle yakalanması mümkün hale gelmiştir (Danto, 2018:352). Peter Henry Emerson fotoğraftaki nesnelerin gözün gördüğü kadar net olmasi gerektiğini ve fazla netliğin fotoğrafın gerçekliğini bozacağını iddia etmektedir (Akt: Değirmenci, 2016: 68). Video görüntülerinde her yeni görüntü bir önceki görüntüyü yok edip sildiğinden dolayı akılda kalmaya, düşünmeye ve imgeye müsaade edilmemektedir. Analog fotoğrafta ise bir şeyin fotoğrafçı çekildikten sonra o fotoğrafin ne olduğunu anlayabilmek için beklenilmesi gerekmektedir. Bir fotoğrafın neyi gösterdiği ancak banyo işlemi sonrasında görülebilmektedir. Dolayısıyla fotoğrafa dair imge, düşünme, eleştiri, tılsım, estetik, bilinç, ayartma, hayal, çatışma, arzu, sahne, çelişki, simgesellik, inkar, eksiklik, başkaldırı vb her şey analog fotoğrafta gerçekleşmektedir. Fotoğrafın ortaya çıkmasında ertelenen zaman ve bu zaman süresince fotoğrafa anlam kazandırma çabası; çekim ve çekim sonrasından fotoğrafın ortaya çıktığı zamana kadar fotoğrafın göstereceklerinin imgelenmesi; beklentiden fazlasını görme; hayal kırıklıkları; yanılsamalar vb insani nitelikler analog fotoğrafın özellikleridir ki fotoğrafın gerçek olan tarafı ve gerçekliğin insani olan tarafı analog fotoğraflarda elde edilebilmektedir. Fotoğraf görüntüsü hassas yüzeye düşen ertelenmiş 1şık etkisiyle ortaya çıkmaktadır (Palalı, 2017:65). Işığın ertelenmesindeki kasıt fotoğrafın çekilmesinden daha sonra görülebilmesidir. Dolayısıyla fotoğrafi, cisimlerden yansıyan 1 şık parçalarının makineye ulaşmasından sonraki süreçlerde beliren şey olarak tarif edebiliriz. Bundan dolayı fotoğrafın bize neyi göstereceğini veya neyi gizleyeceğini anlayabilmemiz için imgeye, düşünmeye, hayale, yanılsamaya ve gerçekliğin algısal bağlantısına ihtiyacımız vardır. Barthesin görünenler ve görünmeyenlerle alakalı düşün hayal kırlklı̆̆ı söyleminden bunu anlamalıyız.

\section{3-3 Etkisel Bağlamda Fotoğraf:}

"Studium; insan için bir tat, genel, hevesli, ama tabii ki özel keskinliği olmayan bir tür kendini verme punctum; studiumu delen, sahneden yükselen, ok gibi dlşar firlayan ve bana saplanan şey, iz yara, ısırık, kesik ve küçük deliktir" (Barthes, 2016:39-40).

Studium aşık olma düzeyinde değil hoşlanma düzeyinde olan şey yarım tutku, heves, arzudur. Bilgi, temsil ve gösteri niteliğindeki her şeyde studium etkisi oluşabilir; özel etki, ayrıntı ve herkesten gizlenmiş olan ve sadece bana görünen ve kırbaçlayan ise punctum etkisini ifade eder. Gerçekliğin bütünsel olduğu yani ikileştirmediği, kararsız bırakmadığı, ikiliği barındırmadığ1 fotoğraflar studium fotoğraflardır. Bu fotoğraflarda insanı çeken ya da üzen bir ayrıntı niteliği taşıyan veya kırbaçlayan herhangi bir etki oluşmamaktadır.

Fotoğrafın hazır kodlarla insanlara sunulduğu görüntülerde insanları delebilecek punctum etkisinin oluşması mümkün değildir. Studium her zaman kodlanmış punctum ise kodlanmamıştır (Barthes, 2016:67). Bir fotoğraf her ne kadar açık bir biçimde çekilirse çekilsin ve görünen şeyin haricinde başka bir şeyin olmadığı düşünülürse düşünülsün fotoğraf çekildikten sonra-yani fotoğraf henüz gözükmeden- punctum etkisi görüntü ortaya çıkmadan da belirebilmektedir (Barthes, 2016:67). Bu durum punctumun düşünce ile ilişkisini açıklamaktadır. Zaten fotoğrafı en iyi şekilde görebilmek düşünebilmek veya gözleri kapatmakla mümkün olabilmektedir. Barthes için punctum dikkatlice bakıldığında ortaya çıkan değil gecikerek ortaya çıkan şeydir (Değirmenci, 106:139). Dolayısıyla punctumun düşünceyle, imgeyle, hayal kurmayla, yanılsamayla yakın ilişkisi bulunmaktadir.

Analog fotoğraflarda punctum etkisi oluşurken dijital fotoğraflarda sadece studium etkisi oluşabilmektedir.

Turkish Studies - Applied Sciences, 15(1) 
"dijital imgenin punctumla işleyen bir alan olmadı̆̆ını, bunun yerine geçmişin modern temsillerine ilişkin birtakım uzlaşımlarla çevrili bir studium alanının dijital imgenin temsil alanını oluşturduğunu belirtmek mümkündür"'(Değirmenci, 2016:232).

Studium fotoğrafların etki bağlamında insanlar üzerindeki sadece şok etkisi oluşturabildikleri düşünülmektedir. $\mathrm{Bu}$ şok etkisi ise sadece bağırmakta lakin insanları yaralayamamaktadır. Yani, fotoğrafta insani değerlere etki eden ve bir süreliğine etkisini sürdüren fotoğraflar kişileri şoke etmektedir. (Barthes, 2016:47). Şok fotoğraflar bir anda algılanıp kolaylıkla unutulabilen fotoğraflardır (Palalı, 2017:89). Şok fotoğraflar sadece etkileşim oluşturmaktadır ve bu türden fotoğrafların davranıș değișikliği ve tepki üretmesinin mümkün olmadığına inanılmaktadır. Böylesi fotoğrafların çok fazla konuşmadıkları iddia edilir. Bağırmaları mümkündür ancak punctumda olduğu gibi yaralamaları, incitmeleri, örselemeleri imkânsızdır. Fotoğraf izleyiciyi sarsmalıdır; izleyici fotoğrafa nasıl yaklaşacağını belirlemekte zorlanmalıdır (Benjamin, 2015:27). $\mathrm{Bu}$ durum ancak analog fotoğrafta oluşabilen punctum etkisiyle mümkün olmaktadır. Dijital fotoğraflar hazır imgeler üzerinden etkisini yürüttüğü için bu fotoğraflardan punctum etkisi beklenilmez; bu fotoğraflar sadece şok etkisi yaratabilirler ve bu şok zaman sonra etkisini tamamen kaybetmektedir (Ökten, 2013:14). Analog fotoğrafta punctum etkisi taşıyan görünümlerde belirsiz bir ayrıntı kişiyi kendine müptela kılabilmekte; görüntünün özgünlüğü fotoğrafa bakışı, değerlendirmeyi, düşünmeyi ters yüz edebilmekte; küçük bir ayrıntı genleşerek fotoğrafın tamamını kaplayabilmektedir. Fotoğrafta görünen asıl şey- belki de tek şey- ayrıntının genleşmiş halidir.

Savedoff, görüntünün gerçekliğine müdahale edilmesinin (öznel yanının yok edilmesinin) içe işleyen etkiyi yok edeceğini iddia edtmektedir (Savedoff, 2018:143). Baudrillard, gerçek değerli bir fotoğrafin müdahalelerden bağımsız olması gerektiği ve imgenin ancak yönlendirmeler olmaksızın gerçeklikle bağlantı kurabileceğini acheiropoiêque kavramıyla açıklamaktadır.

Fotoğrafın dijitalite ile ilişkisi görünümün gerçekliğe olan sadakatini yok etmiştir ve gerçekliğe duyulan güven ters yüz olmuştur (Walden, 2018:17). Dolayısıyla bu türden fotoğraflar insanlar üzerinde herhangi bir etki uyandırmamaktadır. Anın görüntüsünü dijital biçimde ortaya çıkaran fotoğraflara alıştıkça bu türden fotoğrafların etkisini kaybettiği söylenmektedir (Savedoff, 2018:166). Analog fotoğraftan dijital fotoğrafa geçişle birlikte fotoğrafin insanlar üzerindeki iletişim alanı yüzeysel etkileşime evrilmektedir. Analog fotoğrafçıllğın etik alanı kırılganlığı, eleştirmeyi, sorgulamay1, ironiyi, ideolojiyi, düşünmeyi, imgeyi, siyasi bilinci, huzursuzluğu severken dijital fotoğrafçılıkta gelip geçici yapay hisler söz konusudur. 1972 yılında Amerika'nın işgal ettiği Güney Vietnam'daki bir çocuğun kolları açık vaziyette, çıplak bir biçimde fotoğraf makinesine doğru koştuğu fotoğraf bütün toplumlar üzerinde etkili olmuş bir görüntüdür. Analog fotoğraf çıktısı savaş, mücadele, yokluk, hastalık ve ideoloji fotoğrafları kișilere yetersizlik duygusu vermekte ve insanları tutuklamaktaydı (Berger, 2017:50). Kişi bu fotoğraflara baktığında fotoğraf tarafindan yakalanmakta ve başkasının çektiği acı fotoğrafı delip geçerek bakan kişiye sirayet etmekteydi. Keder ve öfke ile dolan insanın iç dünyası yerle yeksan olmakta, insan ne kadar bu fotoğrafların etkisinden kurtulmaya çalışsa da fotoğraf insanı yakalamakta ve duygu alanına hapseymekteydi. Analog fotoğraflarda bu türden etki uyandıran fotoğraf sayısı artırılabilir. Susan Sontag 1945 yılında Santa Monica'da bir kitapçıda tesadüfen gördüğü savaş fotoğraflarından aşırı derecede etkilenmiştir.

"O ana kadar hiçbir şey beni bu kadar keskince, derinden ve anında deşmemişti... Bir sınıra dayanmıştım ve bu salt dehşetin sınırı değildi; tesellisi mümkün olmayan bir kedere düşmüş, yaralanmıştım, ama duygularımın bir kısmının katılaşmaya başladı̆̆ını da hissetmiyor değildim; içimde bir şey ölürken, bir şey de hala feryat edip duruyordu. Istırap çekmek bir şeydir, o ustırabınbilinci ve şefkat duyma yeteneğini arttırması gerekmeyen-fotoğraf görüntüleriyle yaşamak başka bir şey... Öylesi görüntülere bir kez baktıktan sonra, daha fazlasını-sonra daha fazlasınt- görmenin yolu da açılmış olur. O görüntüler insanı olduğu yere mihlar. O görüntüler insanı uyuşturur” (Sontag, 2011:24-25). 
Dijital bir fotoğraf görüntüsünün böyle bir etkide bulunması mümkün olamamaktadır. Çünkü dijital fotoğrafçılıkta ezilen insanların, sömürülenlerin, açlıktan ölmek üzere olanların, katliama uğrayanların görüntüleri gerçek bir iletişim etkisinden ziyade gelip geçici hisler oluşturmaktadır. Dünyanın her tarafinda muazzam büyüklükte katalog oluşturan dijital çıktı fotoğraflar o kadar fazlalaşmıştır ki; sefalet ve adaletsizliği gösteren fotoğraflar herkesi vahşetle aşina hale getirmiş ve dehşetengiz olan sıradan ve bildik hale gelmiştir (Sontag, 2011:25).

Kendi başlarına doğrudan her şeyi açıklayan ve yazıyla açıklanmaya ihtiyaç duymayan fotoğrafların analog fotoğraflar olduğu düşünülmektedir. Fotoğrafların suskunluğu onları cazip hale getirmiş̧tir lakin suskunluğun yanı sıra bu görüntülerde kışkırtıcı imajlarda mevcuttur. Dijital fotoğrafların ise insanlar üzerinde iletişimsel bağlamda kayda değer olmayan geçici şok etkisi uyandırdıklarına inanılmaktadır. Dijital fotoğraflar insanlar üzerinde herhangi bir punctum etkisi oluşturmadan kayıp gitmektedir. Bunların etkisi olsa olsa şok etkisi olabilmekte; şok etkisi bir süre sonra zihinlerden kurtulmakta ve fotoğraf unutulmaktadır (Ökten, 2013:34). Bir fotoğraftan beklenen en önemli şey fotoğrafin hiçbir şekilde yapılması mümkün olmayan bir durumu anlatması yani konuşmasıdır; fotoğraf hakikat adına konuşmalıdır (Sontag, 2011:132). Fotoğrafın gerçek değerde bir fotoğraf niteliği taşıyabilmesi soru sormasına, eleştirebilmesine ve düşündürtmesine bağlıdır. 1937'de Andre Kertesz'in fotoğraflarının Life Dergisi tarafından geri çevrilmesine neden çok fazla konuşuyor olmaları gösterilmiştir. Bu fotoğrafların çok fazla konuşuyor olmaları imge ile var olan bağlantısı nedeniyle gerçekliğe gönderme yapmakta ve insanları etkilemektedir.

\section{3-4 Fotoğrafta Sır ve Gizem:}

Benjamin fotoğrafların biriciklik niteliğinden yoksun olmasını eleştirmiştir. Ona göre biriciklik niteliği taşıyan bir fotoğrafin aurası olabilmektedir. Biricik olan fotoğraf dönüştürücü ve fikirseldir. Lakin fotoğrafta aurayı bulabilmek oldukça güçtür. Kısıtlayıcı, sinırlayıcı ve imge barındırmayan fotoğrafların insanlar üzerinde eleştirel bir bilinç oluşturması mümkün değildir. Teknik olarak yeniden üretilebilirlik çağında solan şey ortaya çıkan eserin aurasıdır (Benjamin, 2015:15). Teknik olarak yeniden üretimde çoğaltılan ve gerçekliği başkalaştırılan nesne katmanlarından ayrıştırılmaktadır. Bu durum hem eserin biricikliğini ortadan kaldırmakta hem de gerçekliğin taşıdığı değer yok olmaktadır.

"Aura (hale) nedir? Zamanın ve mekânın oluşturduğu tuhaf bir ăg: ne kadar avucunuzun içindeymis gibi görünürse görünsün, belli bir mesafede duran bir şeyin tek bir kezlik görünümü. Bir yaz gününde anın ya da saatin de görünümün parçası olmaya başladığı noktaya kadar bir dăg silsilesinin ufukta oluşturduğu çizgiyi ya da gölgesini kendi üstüne düşüren bir dal parçasın seyredere uzanmak-işte o dağların, o dal parçasının halesini hissetmek denen şey budur" (Benjamin, 2018:24-25; Benjamin, 2015:18; Leslie, 2019:114).

Auranın hissedilmemesinde iki etmeni ortaya koyabiliriz. Bunlardan ilki kitlelerin nesnelere yakın olma istekleri, ikincisi ise nesneleri yeniden üreterek sindirip nesnenin biricikliğini yok etme tutkuları (Benjamin, 2015:18). Auranın yok edilmesi yeniden üretim yoluyla türdeşliğin artmasına ilişkindir (Price, 2004:68). Bu türden fotoğraflarda kopyalar özgün fotoğrafların önüne geçmektedir. Auranın yok edilmesi fotoğrafin gerçek niteliğini bozmaktadır. Yeniden üretim sonucunda her yerde karşımıza çıkan aynılık aurayı ortadan kaldırmıştır. Mekanik yeniden üretim süreci, biriciklik ve özgünlük taşıyan fotoğrafin durumunu değiştirmiştir (Değirmenci, 2016:64). Benjamin'de iki farklı aura kullanımı olduğunu söyleyebiliriz:

1- $\quad$ bir fotoğrafin biricik ve özgün olması

2- $\quad$ nesnelere ait gerçekliği örten gerçekliği gizleyen sis, perde (Price, 2004:69).

Birinci kullanımda aura saygı duyulan nesne çevresinde toplanan imgeler bulutu ve çağrışımları; ikinci kullanımda ise nesneyi örten atmosfer veya hale anlamını karşılamaktadır (Price, 2004:179). Aura yok edilerek hem imgeler bulutu hem de atmosfer yok edilmiştir. Daha geneliyle

Turkish Studies - Applied Sciences, 15(1) 
bakan nesneye karşılık verilmesi görüntünün aurasını hissetmek anlamına gelmekteydi ki artık böylesi fotoğraflarla karşılaşmak neredeyse imkânsız hale gelmiştir. Bakan bir nesnenin bakışına karşılık verebilmek olanaksızlaşmış ve bilinçten uzaklaşmış fotoğraflar ortaya çıkmıştır (Price, 2004:180). Nesnelerin katman kaybetmek yerine görünmez bir katman daha kazanmaları auray1 oluşturmaktadır. Walter Benjamin'in aura kavramına karşılık Barthes tayf (hava) kavramını kullanmıştır. Tayf; görünüş, yayılım, ifade kavramlarını içermektedir.

Fotoğraf içsel gerçeklik ile dışsal gerçeklik arasındaki bir dengedir (Ökten, 2013:118-119). Yönlendirilmiş ve hazır kod haline getirilmiş gerçeklik, fotoğrafçılığın ruhuna ters düşmektedir. Michael Zimmerman için güncel (dijital) fotoğraf; her şeyin hazır hale getirildiği, gizemin ve sırrın yok olduğu, önceden hazırlanmış kodların egemenliğindeki teknolojik çıktılardır (Akt: Değirmenci, 2016:141). Dijital fotoğraf makinesi insanları bellekten, düşünceden ve imgeden koparmıştır (Berger, 2017:74-75). Çünkü dijital fotoğrafta her şey hazır kalıp halde beklemektedir. Deklanşöre basılmadan önce neyin nasıl görünmesi gerektiğine ilişkin her şey makinenin işlemcisinde kayıtlı haldedir. Barthes fotoğrafın insanlar üzerindeki punctum ve studium etkisini değerlendirirken fotoğrafin sır ve ifşa ile olan ilişkisini de değerlendirmeye almıştır. Ona göre zorla gösterilen, ifşa ettirilen ve bütünsel bağlamda gerçek kılınmaya çalışılan fotoğraflar sadece studium etkisi oluştururken sır niteliği taşıyan, gizli bırakılan ve yanılsamaya olanak sağlayan fotoğraflarda punctum etkisi oluşmaktadır. Erotik fotoğraflarda punctum etkisi oluşabilirken pornografik fotoğraflarda punctum etkisi oluşmamaktadır (Barthes, 2016:73). Bu durum erotik fotoğraflarda bir şeylerin gizlenmesiyle pornografik fotoğraflarda ise her şeyin ifşa edilmesiyle alakalı bir durumdur. Fotoğraf her şeyi ifşa etmemeli yeteri kadar örtük olmalıdır (Palalı, 2017:69). Fotoğrafa her bakanın göremeyeceği ancak ikincil bir bakışla ortaya çıkabilecek bir gerçeklik veya mesaj bulunmalıdır. O gerçeği görebilmek veya o mesaj1 alabilmek için fotoğraftan kopmak, başka bir yöne bakmak, beklemek, imgelemek, hayal kurmak, düşünmek ya da gözleri kapatmak gereklidir. Fotoğrafa ilk bakışta gözükmeyen ancak zaman sonra ortaya çıkan şeyler Barthes tarafından kör alan kavramıyla da ifade edilmektedir. Kör alan fotoğrafın özünde olan bir şeydir. Kör alanı ortadan kaldırmaya çalışmak fotoğrafın gerçekliğiyle oynamak demektir. Kör alan fotoğrafta anlama sızan ve fotoğrafı oluşturan şeydir. Nesneleri örten sırrın yok edilmesi auranın darmadağın edilmesi anlamını taşımaktadır (Benjamin, 2015:19). Böyle bir anlamda dünyadaki her şey benzer bir gerçekliğe dönüştürülerek evrensel bir algı hegemonyası oluşturulmuştur. Zaten yeniden üretim araçları böyle bir algının sürdürülmesinde gerçekliği bütünsel anlamda aynı hale getirmişlerdir. Böylesi bir gerçekliğin kitlelere uyumu ve kitlelerin gerçeklikle uyumu kitlelerin düşünce yapıları ve algılamaları için son derece önemlidir.

Analog fotoğrafçılıkta şeffaflık olumlu bir anlam taşırken dijital fotoğrafçılıkta olumsuz bir anlama bürünerek her şeyi ifşa eden bir anlama evirilmiştir (Walden, 2018:14). Dijital görüntülerin her şeyi görme ve göstermeye ilişkin bir çabası vardır (Değirmenci, 2016:231). Yani her şeyi aleni, şeffaf, görünür kılmaya çalışan dijital mantık eksiklik, sır ve kusuru fotoğrafın nitelikleri dışında tutmaya çalışmaktadır. Örneğin HDR fotoğraflar gerçekçi olmayan dinamik alanlar üreterek gerçekten daha gerçek imajlar üretmekte yani fotoğrafik olanı post fotoğrafik süreçlere taşımaktadır. $\mathrm{Bu}$ durum gerçekliğin fraktal hale gelmesinin iyi bir örneğidir. Bir şeyin bütünsel olarak şeffaf hale getirilmesi hem onun delici etkisini hem de gerçekliğini değiştirmektedir. Yeniden canlandırma ve imge bir şeylerin sır haline getirilmesiyle yani maskelenmesiyle mümkün olmaktadır.

Gerçeklik, fotoğrafın kendisi ve çekmiş olduğu gerçeklik arasındaki özdeşlik ve benzerlik temelinde şekillenen estetik kuram şekliyle tarif edilmektedir (Bate, 2013:60). Lakin gerçeklik fotoğraf ve çektiği nesne arasındaki benzerlikten ziyade yanılsama barındıran ve görmeyi farklı kılan maskeyi değerli hissettirdiği zaman gerçek olmaktadır (Burgin, 1997). Bu türden bir gerçeklik imge, bakış, sahne, gösteri, ayartma, derinlik ve benzeri bilinç nitelikleriyle iç içedir. Barthes fotoğrafin bilinç ile ilişkisini noesis kavramıyla açıklamıştır (Barthes, 2016:131). Noesis fotoğrafın bilinçle ilişkili olan bütün alanlarını kapsamaktadır. Dolayısıyla noesisin analog fotoğrafta daha belirgin 
olduğu düşünülmektedir. Dijital fotoğraf için önemli olan görünümlerin önündeki perdenin yok edilerek arka plandaki gerçekliklerin gösterilmesidir (Walden, 2018:26). Bazı fotoğraflarda bakarken gördüğümüz şeylere değil de görünmeyenlere bakılır. Çünkü insanların gördükleri şey gelip geçici niteliktedir. Fotoğrafi asıl fotoğraf yapan şey görünmeyenlerdir ki bu görünmeyenler fotoğrafı ebedi yapmaktadır (Price, 2014:121). Analog fotoğraf gerçeği değiştiren veya dönüştüren bir niteliğe sahipken dijital fotoğraf gerçekliği kendi gerçekliğine dönüştürmüştür. Bilincin devre dışı bırakıldığ1 dijital fotoğraflar görüntüyü müstehcen hale getirerek sırları ifşa etmekte ve her şeyi görünür kilmaktadır.

İmgenin analog fotoğrafla yakın ilişkisi vardır; yani maddi yüzeyler üzerinde çeşitli iz ve işaretlerin oluşması için düşünmeye, hayal kurmaya, yanılsamaya ihtiyaç duyulmaktadır (Değirmenci, 2016:191). Ancak dijital fotoğrafta iz ve işaretlerin oluşması için herhangi bir zaman dilimi içerisindeki düşünme pratiklerine değil kodsal verilerin anlık olarak enformasyona dönüşmesine gerek duyulmaktadır. Maske, saf olduğu sürece anlam demektir (Barthes, 2016:50). Anlamın saf gürültü ile çevrelenmesi maskeyi ifade etmektedir. Maske fotoğrafi çekilen şeyin konuşmasına ve fotoğrafa bakan kişinin düşünmesine neden olmaktadır. Maskenin ortadan kalkması dışsal müdahalelerle değil fotoğrafa bakan kişinin kendi bilinciyle gerçekleşmektedir (Barthes, 2016:128). Fotoğrafın bilince müdahale etmeden anlam oluşturması analog fotoğrafa ilişkindir ki Barthes bu durumu ur-doxa kavramıyla açıklamaktadır (Akt: Palalı, 2017:31).

Fotoğrafçılıkta gözlem sürecinin bilinçle yakın ilişkisi vardır. Bir fotoğrafın gerçekliği görünmez olandır (Berger, 2017:37). Görülmüş olanın kaydedildiği fotoğrafta sürekli görünmeyene ve yanılsamaya da değer verilmelidir. Fotoğrafta gösterilmiş olan gösterilmemiş olanı da akla getirmelidir (Berger, 2017:38). John Berger için bir fotoğrafın gerçekliği mevcut olanı göstermesinin yanı sıra mevcut olmayanı da düşündürtmesidir. Gerçekte fotoğraflar hakikate gönderme yapan bir görünümü imgeleme sürecidir.

"Fotoğraf, insan gözünün ayrıştırıcı süzgecinden geçmiş; duygusal, düşünsel, estetik ve algısal müdahaleler görmüş, bu açıdan kişiselleştirilmiş bir fotoğraftır” (Ökten, 2013:81).

Fotoğrafçı ve fotoğraf makinesi arasındaki özgün ve munis ilişkinin dijital fotoğrafçılıkla birlikte yok olduğu; ortaya çıkan fotoğrafların garip ve yalancı olduğu iddia edilmektedir. Fotoğraf kendisine bakanlara her zaman için objektif olma vaadinde bulunmuştur ki fotoğraf makinesinin önüne takılan objektif kelimesi de gerçekliğe sadık kalmaya gönderme yapmaktadır (Leslie, 2019: 33-34). Elbette ki fotoğrafin amacı gerçekliği keşfetmektir. Lakin bu gerçeklik gerçekliğin tözüne sadık kalan gerçekliktir. Bu türden gerçeklikler gerçeği aşıp geçmemeli ve sırrı, aurayı, betimlemeyi yok etmemelidir. Benjamin için de fotoğraf gerçekliği aktarırken sınırlarını bilmeli ve göstermesi gereken şeylerin doğasını bozacak aşmalarda bulunmamalıdır. Denilebilirse fotoğraf fotoğrafı çekilen şeyin tasvirine sadık kalmalıdır. Bu durum göze konuşan nesneyle objektife konuşan nesnenin farklılığıyla karıştırılmamalıdır. Analog fotoğrafta gözün göremediği bazı nesneler kendilerini objektife gösterirler ve bu nesneler ancak daha sonra bakıldığında fark edilirler. Burada nesneler bizim göremediğimiz yeni bir nesne düzleminde görünür hale gelmektedir. Görmenin yeniden doğuşu olarak adlandırabileceğimiz bu durumda optik bilinçaltı yeni şeyleri görmeyi keşfetmektedir (Leslie, 2019:168). Ancak dijital fotoğraf görünen şeyleri daha görünür k1lmaya, mahremiyeti yok etmeye, sırrı bozmaya, aurayı paramparça ederek ifşa etmeye programlanmıştır. Bilgisayar programcılığı mantığına dönüştürüldükten sonra fotoğraf ve birey arasındaki mahremiyet ve sır kaybolmuştur ve fotoğraf makinesi sınırsız sayıda görüntü oluşturan kusursuz bir seri üretim aracı halini almıştır (Baudrillard, 2012:30).

\section{3-5 An Kavramının Değişimi:}

Karar anı kavramı Henri Carter-Bresson'un bir fotoğrafın çekilmesiyle alakalı deklanşöre basılan en doğru zaman dilimini ifade etmek için kullandığı terimdir. Bu anın eylem öncesi, eylem anı ve eylem sonrası düşünce ve yorumla yakın ilişkisi vardır. Karar anı (decisive moment) 
kaygısıyla ortaya çıkan fotoğrafı Henri Carter-Bresson, "Kompozisyonu dinç ve zengin, içeriği dışıına ışık saçan, bütün bir hikâyeyi tek başına anlatan yegâne fotoğraf”" (Akt: Bate, 2013:92) olarak ifade etmektedir. Aynı anlama gelebilecek Gotthold Leising'in gebe an kavramı da mevcuttur. Roland Barthes (2016:74) fotoğraf çekmek için en uygun zaman anlamına gelen doğru an, eleştirel an ve elverişli an anlamlarını kapsayan kairos nosyonunu kullanmıştır. Walter Benjamin fotoğrafı çekmede geçmiş, şimdi ve geleceği birleştiren yoğun adanmışlık anı olgusunu kullanmıştır (Akt:Leslie, 2019:87) Karar anı, gebe an, yoğun adanmışlık anı ve kairosun bilinç, düşünce ve yorumla yakın ilişkisi vardır. Bilincin analog fotoğrafta daha belirgin olduğunu kabul edersek bilinçten bağımsız biçimde ortaya çıkan dijital fotoğraflarda dijital an terimini öne sürebiliriz (Green, 1994:34). Dijital anın bilinç, yorum ve düşünceyle olan ilişkisi ise yok denecek kadar azdır. Fotoğrafta geçerli olması gereken yegâne gerçeklik John Grierson'a göre derin yorum olmalıdır. Ona göre yorumun stüdyo kaynaklı olması, belgeselden alınması veya müzik salonundan gelmesi önem fark etmemekte önem kazanan şey yorumun derinliği olmaktadır (Grierson, 1998:1927-1933). Analog imajların mimesis ve doğrudanlıkla ilişkili bir çeşit yanılsamalar ile yakın ilişkisi varken dijital imajların görüntüde gerçekleşen bir çeşit simülasyon ve bütünsel gerçeklikle ilişkisi vardır (Değirmenci, 2016:229). Aynı şekilde analog fotoğrafların gerçekleşme süreci geçmiş, şimdi ve geleceği kapsayan zaman akışkanlığıyla bağlantısı varken dijital fotoğraflar an içerisinde üretilip tüketilmektedir. Yani dijital fotoğraf an içerisinde kendi görsel nitelikleri dışında farklı bir zaman dilimiyle ilişkilendirilmemektedir.

Dijital fotoğrafçılıkta çekilen görüntü aynı anda ekrandan görülebilmekte dolayısıyla imge, düşünme, eleştiri, tılsım, etik, estetik vb şeyler gerçekleşmemektedir. Akış yerine kesin bir zaman diliminin ortaya konulduğu ve fotoğrafin beklendiği analog fotoğraf akılda tutulabiliyorken bir akış1 yansıtan dijital fotoğraflar gelip geçici yüzeysel pathoslar yaratmaktadır. Dijital fotoğrafçılık, bilgisayar mantığına uygun 0 ve 1'lerden oluşan binary sistemin imge ve gerçekliği aynı ekran üzerinde birleştirdiği ve düşünceyi devre dışı bıraktığ sistemdir.

Fotoğrafik görme herkesin baktığı ancak sıradan bularak göremediği şeylerdeki güzellikleri keşfetme yeteneğine verilen isimdir (Sontag, 2011:108). Fotoğrafik görmede salt bakmadan ziyade görerek farklılığı ortaya koyabilecek görüntülerin elde edilmesi önemlidir. Analog fotoğraflarda fotoğrafi değerlendirirken görsel algı gerekliyken dijital fotoğraflarda görme eylemi yeterlidir. Bilinç düzeyindeki davranışlarımızı belirleyen görsel algılamada bilgi birikimi, yorumlama, imge, düşünme, yanılsama önemliyken görme eyleminde herhangi zihinsel bir faaliyete ve dolayısıla düşünme pratiklerine gerek yoktur (Ökten, 2013:38-39).Fotoğraf çekmede doğru an önemlidir. Doğru anda bir şeyin fotoğraflanmasında yepyeni bir bakışla bir şeyin tek seferde doğru fotoğraflanması başarı ölçütüdür. Doğru an ve fotoğrafik görme ile elde edilen bir fotoğrafın estetik ve ahlaki tarafı bulunmaktadır. Fotoğraf bilindik bakma biçiminin kalıplarını yırtarak farklı bir görme (yani fotoğrafik görme) şekli kazandığında etkisi sürekli hale gelmektedir.

\section{Sonuç}

Görüntünün farklılaştırılmış formatları gerçek olana tercih edilmektedir. Fischer'e göre gerçeklik gerçekte sistem tarafindan yok edilmiştir. Çünkü mevcut kapitalist sistem gerçekliği kendi himayesine alarak ona yeniden bir anlam yüklemesi yapmıştır (Yaykın, 2017:40). Mutlak gerçekliği kendi gerçeklik biçimine dönüştüren sistem göreceli gerçeği önemsiz hale getirerek ideolojik sürdürülebilirliği için farklı bir gerçeklik formatı üretmiştir ki bu üretim sistemin devamlılığ 1 için hizmet eden yeniden üretimin kendisidir. Fotoğrafta da mutlak gerçekliğin egemen k1lınması amacıyla ortaya çıkartılan dijital gerçeklik insani nitelikleri önemsiz hale getirerek tamamen belirlenmiş olana mutlak itaati kabul ettirmiştir.

Fotoğrafı fotoğraf makinesini işleyişinden ziyade fotoğrafçının düşüncesinde aramak gereklidir. Çünkü fotoğrafi ortaya çıkaran şey zekâ, imgelem, yaratıcılık, bilinç ve betimleme yeteneğidir. Bu anlamda fotoğrafik yaratıcılık makineden ve fotoğraf teknolojilerden çok daha 
anlamlı ve önemli olmalıdır. Fotoğraf makinesinin herhangi bir amacı söz konusu olamazken insan düşüncesinin amaçlı dönüşüm hedefi bulunmaktadır. Fotoğraf çekme eyleminde gerçeklik sadece cisimlerden yansıyan ışık ile değil yanılsama ile de ilişkili olmalıdır. Analog fotoğrafta çıplak gözle görülen gerçeklikle objektifin gördüğü gerçeklik her seferinde aynı olmamaktadır. Lakin dijital fotoğraf kendi fotoğrafik gerçekliğini oluşturarak önceden belirlenmiş yazılım ve kodlara uygun olan süper gerçekliği yani sayısal gerçekliği dünyaya yaymaktadır. Fotoğrafçı karşılaşmış olduğu görünümlerde yanılsamalarla ilintili imgelemi devreye sokmalıdır. Çünkü imge görünen gerçekliğin haricinde yeniden yaratılmış ve üretilmiş bir gerçekliği ortaya çıkarmalıdır (Ökten, 2013:79).

Gerçekliğin saf ve anlamlı olduğu fotoğraf örnekleri dijital fotoğrafçılıkla birlikte yok olup gitmektedir. Çünkü artık gerçekliğin yanılsama yönü yok edilerek salt gerçeklik, süper gerçeklik, bütünsel gerçeklik olarak adlandırabileceğimiz bir gerçeklik dünyasına ve süper fotoğraf, bütünsel fotoğraf, post fotoğraf, bütün fotoğraf diyebileceğimiz fotoğrafçılık dünyasında geçilmiştir. Dijital görüntüler kendisinden başka hiçbir şeye gönderme yapmayan ve temsil niteliği barındırmayan kodlanmış gerçeklerdir. Ancak bu durum dijital görüntülerin baskın fotoğrafik görüntü olduğu gerçeğini değiştirmemektedir. Gündelik yaşamın her alanına etki eden dijital görünümler fotoğraf kavramının doğasını kökten değiştirmiştir. Dijital teknolojilerle elde edilen görüntülerle fotoğraf artık programlanabilir bir olgu halini almıştır (Değirmenci, 2016:236). Fotoğrafın mevcut dijital üretim koşulları fotoğrafı bütünsel gerçekliğe ait bir çeşit üretim ve işlem aracı haline getirmiştir. Teknolojik cihazlar gerçekliğin derinliğine öyle fazla nüfuz etmiştir ki gerçekliğin saf görünümü yok olmuştur (Benjamin, 2015:43).

Çoğaltılmış kopya fotoğraflar orijinallerinden çok zor biçimde ayırt edilebilmektedir. Kopyanın temel özelliği geçicilik ve çoğaltılabilirlik olduğu gibi orijinalin temel özelliği ise biricikliği ve iç içe örülmüş bütünlügüdür. Nesnesin kabuğundan kopması ve halenin paramparça olması çoğaltma yoluyla biricik olanın alt edilmesidir. Gerçekliğin basit bir kopyası gerçeklik hakkında her zamankinden daha az şey ifade ederken (Benjamin, 2018: 35) bu gerçekliğin teknoloji ile olan ilişkisi önce yanılsamayı iyice azaltmış son kertede post fotoğrafik süreçte yanılsama tamamen yok edilmiştir.

Fotoğraf makinesindeki dijital görüntüleme teknikleri ve beraberinde getirmiş olduğu görüntüdeki manipülasyon kolaylıkları bu işin daha masumane olduğu negatif sürecin yerini almıştır. Bundan böyle aracın (fotoğraf makinesinin) sunduğu gerçeklikler üzerinde yeni sorunlarla karşılaş1lmaktadır (Walden, 2018:13-14). Dijital teknolojilerin fotoğraf üzerindeki mutlak ve sürekli etkisi fotoğraf hakkındaki genel anlayışımızı değiştirmiştir. Bundan böyle fotoğrafları gerçeklikle ilişkilendirebilmemiz mümkün değildir (Cohen and Meskin, 2004:206). Fotoğrafların çekim esnasında ve çekim sonrasında çeşitli teknolojilerle doğallıklarından koparılması ve teknolojik formatlara dönüştürülmesi safiyetlerinin bozulmasına neden olmaktadır. Bir fotoğrafa müdahale ve manipülasyon ne kadar az ise o fotoğraf o denli özgün ve gerçekçi bir fotoğraf olmaktadır (Sontag, 2011:63).

Analog fotoğrafçılıkta fotoğrafik bir üslup söz konusudur. Fotoğrafi çeken kişinin fotoğrafik düşüncesi, fotoğrafa bakan kişinin belleğinin işleyişinde fotoğrafik bir bilinç söz konusudur. Dolayısıyla ortaya çıkan fotoğrafta ahlaki ve estetik bir görüntü hem fotoğrafı çeken için hem de fotoğrafa bakan kişi için mevcuttur. İnsan belleği ve fotoğraf makinesi görsel olarak algılanan şeyden daha fazlasını özümseyerek bunları daha sonra incelemek üzere kaydetmekteydi. Bir fotoğraf elde edilirken neyin ortaya çıkacağı tam belli olmadığı için zihinde sürekli bir beklenti, öngörü ve kavrayış söz konusuydu. Çünkü ortaya çıkacak olan görüntüde neyin görüleceği tam olarak belli değildi. Bu belirsizlik hem teknik anlamda hem de ortaya çıkacak gerçeklik bağlamındaydı. Zamandan bir anı yakalayıp onu düşünen bellek bilinçli bir kavrayış halini alarak fotoğrafi özümsemekteydi. Dijital fotoğrafçılıkta ortaya çıkan görüntü anında ekranda belirdiği için belleğin 
herhangi bir kavrayışının olması söz konusu olamamaktadır. Ekranın kendisi doğrudan imgenin yerini almakta ve insani niteliklere bağlı gerçeklik yok olmaktadır.

\section{Kaynakça}

Arnheim, R.(1957). Film and Art. Berkeley: Berkeley University of California Press.

Barthes, R.(1982). Image, Music, Text. London: Fontana Press.

Barthes, R.(2016). Camera Lucida. Çev: Reha Akçakaya, İstanbul: Altıkırkbeş Yayın.

Bate, D.(2013). Fotoğraf Anahtar Kavramlar. Çev: Bahar Şimşek, Ankara: De Ki Basım Yayım.

Baudrillard, J.(2005). Bir Parçadan Diğerine François L'yvonnet İle Söyleşi. Çev: Yaşar Avunç, İstanbul: İnkılâp Kitapevi Yayın Sanayi ve Ticaret A.Ş.

Baudrillard, J.(2016). Kötülüğ̈̈n Şeffaflı̆̆ Aşırl Fenomenler Üzerine Bir Deneme. Çev: Işı1k Ergüden, İstanbul: Ayrıntı Yayınları.

Baudrillard, J.(2012), Neden Her Şey Hala Yok Olup Gitmedi, Çev: Oğuz Adanır, İstanbul: Boğaziçi Üniversitesi Yayınevi.

Bazin, A.(1960). The Ontology of The Photographic Image. Çev: Hugh Gray, Berkeley: University of California Press.

(Aynı eser: Çevrimiçi: https://www.jstor.org/stable/1210183?seq=1\#metadata_info_tab_contents Erişim Tarihi:27.01.2019)

Benjamin, W.(2018). Fotoğrafin Kısa Tarihi. Çev: Osman Akınhay, İstanbul: Agora Kitaplığı.

Benjamin, W.(2015). Teknik Olarak Yeniden-Üretilebilirlik Çağında Sanat Yapıtı. Çev: Gökhan Sar1, İstanbul: Zeplin Kitap.

Berger, J.(2017). Bir Fotoğrafi Anlamak. Haz ve Sunuş: Geoff Dyer, Çev: Beril Eyüboğlu, İstanbul: Metis Yayincilik.

Burgin, V.(1997). “Art, Commonsense and Photography”.(Der.) Jessica Evans in The Camerawork Essays, London: Rivers Oram Press.

Cohen, J. and Meskin, A.(2014). On The Epistemic Value of Photography, Journal of Aesthetics and Art Criticism 62:2.197-210.

Currie, G.(2018). Kral Arthur'un Resimleri: Fotoğraf ve Hikâyenin Gücü, Fotoğraf Felsefesi (Doğanın Kalemi Üzerine Denemeler) içinde. (Der.) Scott Walden Çev. Aylin Ünal, Hüseyin Y1lmaz. İstanbul: Espas Sanat Kuram Yayınları 313-331.

Danto, A. C.(2018), Çıplak Gerçek, Fotoğraf Felsefesi (Doğanın Kalemi Üzerine Denemeler) içinde, (Der.) Scott Walden Çev: Aylin Ünal ve Hüseyin Yılmaz. İstanbul: Espas Sanat Kuram Yayınlar1 333-359.

Davies, D.(2018). Fotoğraflar, Ne 'Anlama Gelir': Cartier-Bresson'un Scruton'a Yanıt1, Fotoğraf Felsefesi (Doğanın Kalemi Üzerine Denemeler) içinde, (Der.) Scott Walden Çev: Aylin Ünal ve Hüseyin Y1lmaz. İstanbul: Espas Sanat Kuram Yayınları 201-221.

Değirmenci, K. (2016). Fotoğrafin İmgeleri Temsil, Gerçeklik ve Dijital Çağda Fotoğraf. İstanbul: Doğu Kitabevi.

Ertuğ, T.(2010).Fotoğraf Sanatı Üzerine. Ankara: Alter Yayıncılık. 
Friday, J.(2005). "André Bazin's Ontology of Photographic and Film Imagery", (in)The Journal of Aesthetics and Art Critism, Volume:63, Issue:4 339-350.

(Aynı eser: Çevrimiçi: https://onlinelibrary.wiley.com/doi/epdf/10.1111/j.0021-8529.2005.00216.x Erişim Tarihi 03.04.2018)

Fischer, E.(1990). Sanatın Gerekliliği. Çev: Cevat Çapan, Ankara: İmge Kitapevi.

Freeland, C.(2018). Fotoğraflar ve İkonalar, Fotoğraf Felsefesi (Doğanın Kalemi Üzerine Denemeler) içinde, (Der.) Scott Walden Çev: Aylin Ünal ve Hüseyin Yılmaz. İstanbul: Espas Sanat Kuram Yayınları 69-91.

Freund, G.(2016). Fotoğraf ve Toplum. Çev: Şule Demirkol, İstanbul: Sel Yayınc1lık.

Frosh, P.(2003). The Image Factory Consumer Culture Photography and Visual Content Industry. Oxford: Berg Press.

Flusser, V.(2009). Bir Fotoğraf Felsefesine Doğru. Çev: İhsan Derman, İstanbul: Hayalbaz Kitapları:

Green, J.(1994). “Pedro Meyer’s Documentary Fictions” Aperture, No:136, Summer.

Grierson, J.(1998), Untitled Lecture on Documentary. in The Documentary Film Movement: An Anthology, (Der.) Ian Aitken, Edinburg: Edinburg University Presss 1927-1933.

Leslie, E. (2019). Walter Benjamin Fotoğraf Yazllarl. Çev: Burcu Halaç ve Tevfik Turan, İstanbul: Kolektif Kitap.

Manovich, L.(1995). The Paradoxes of Digital Photography. Germany: Photography after Photography Exhibition Catalog.

Mitchell, W. J.(1992), The Reconfigured Eye: Visual Truth in the Post-Photographic Era, Cambridge: MIT Press.

Moholy, L.(1939). A Hundred Years of Photography. Harmondsworth: Penguin Press.

(Aynı eser: Çevrimiçi: (https://www.tandfonline.com/doi/abs/10.1080/00043079.1941.11408799 Erişim tarihi: 23.08.2019)

Moholy-Nagy, L.(1927). "Die Photographie in der Reklame” in Photographische Korrespondenz 9, September 1927:2, 257-260.

Ökten, A.İ.(2011). Fotoğraf Yazıları, Ankara: Alter Yayıncılık.

Ökten, A.İ.( (2013). Fotoğrafin Eleştirel Gücü Fotoğraf Yazıları-2, Ankara: Alter Yayıncılık

Özel, Z.(2005). "Fotoğraf Akımları İçinde Gerçekliğin Sunumu”. Yeni Düşünceler. Y11:1, Sayı:1, Haziran: 273-291.

Palalı, A.T.(2018). Fotoğraf, Zihinsel Şey: Bir Henri Cartier-Bresson Kavrayışı. İstanbul: Altıkırkbeş Yayınları.

Palal1, A.T.(2017). Kış Bahçesinden Fotoğrafa (Bir Roland Barthes Yolculuğu). İstanbul: Altıkırkbeşyayınları

Price, M.(2014). Fotoğraf Çerçevedeki Gizem. Çev: Ayşenaz Koş ve Kubilay Koş, İstanbul: Ayrıntı Yayınları

Ritchin, F.(1999). In Our Own Image: The Coming Revolution in Photography. Newyork: Aperture Foundation.

Robins, K. (1992), "The Virtual Unconscious in Post-Photography”. Science as Culture, Vol:3, Issue:1,99-115.

Turkish Studies - Applied Sciences, 15(1) 
Røssaak, E.(2011). Beyond the Photo/Film Divide, Between Stillness and Motion: Film Photography, Algorithims. Amsterdam: Amsterdam University Press.

Savedoff, B.(2018), Belgesel Özerklik ve Fotoğraf Sanat1, Fotoğraf Felsefesi (Doğanın Kalemi Üzerine Denemeler) içinde, (Der.) Scott Walden Çev: Aylin Ünal ve Hüseyin Yılmaz. İstanbul: Espas Sanat Kuram Yayınları 139-166.

Sekula, A.(1984). Photography Against the Grain: Essays and Photo Works. Halifax: Press of the Nova Scotia College of Art and Design, 1973-1983.

Slater, D. (2003), Photography and Modern Vision: The Spectacle of 'Natural Magic'. in Visual Culture, (Der.) Chris Jenks, Newyork: Routledge Press 218-237.

(Çevrimiçi: Aynı eser: http://web.mit.edu/uricchio/Public/Documents/media-in-transition/SlaterPhotography\%20and\%20Modern\%20Vision.pdf Erişim tarihi: 12.10.2019)

Sontag, S. (2011). Fotoğraf Üzerine. Çev: Osman Akınhay, İstanbul: Agora Kitaplı̆̆ı.

Tagg, J.(1988), The Burden of Representation Essays on Photographies and Histories. Minneapolis: Minnesota University Press.

(Çevrimiçi: Aynı eser: http://sites.uci.edu/asianamarthistory2016/files/2016/03/04.06-Tagg Erişim Tarihi: 10.07.2019)

Trachtenberg, A.(2008). Through a Glass, Darkly: Photography and Cultural Memory. Social Redearch: An International Quarterly, 75(1), 111-132.

Walden, S.(2018). Fotoğraf Felsefesi (Doğanın Kalemi Üzerine Denemeler). (Der.) Scott Walden Çev: Aylin Ünal, Hüseyin Yılmaz. İstanbul: Espas Sanat Kuram Yayınları

Walden, S.(2018). Fotoğrafta Gerçeklik, Fotoğraf Felsefesi (Doğanın Kalemi Üzerine Denemeler) içinde. (Der.) Scott Walden Çev: Aylin Ünal ve Hüseyin Yılmaz. İstanbul: Espas Sanat Kuram Yayınları 115-136.

Walton, K. L.(2018). Geçirgen Fotoğraflar: Fotoğrafik Gerçekliğin Doğası Üzerine. Fotoğraf Felsefesi (Doğanın Kalemi Üzerine Denemeler) içinde. (Der.) Scott Walden Çev: Aylin Ünal ve Hüseyin Yılmaz. İstanbul: Espas Sanat Kuram Yayınları 29-67.

Yaykın, M.(2017). Fotoğraf İdeolojisi Algıda Gerçeğin Bozulumu. İstanbul: Kalkedon Yayıncılık.

Yurdalan Ö.(2007). Belgesel Fotoğraf ve Fotoröportaj. İstanbul: Agora Kitaplı̆̆1. 